برنامج تثقيفي تغذوي صحي مُقترح لمعلمات الروضة لتنمية مفاهيم الوعي الوقائي

$$
\text { من مرض السرطان }
$$

اعداد (عاد

الباحثة / سارة رمزي إبراهيم سليمان'

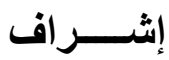 \\ أ.د / إبتهاج محمود طلبه
}

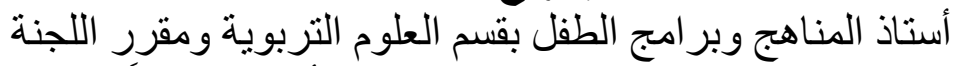

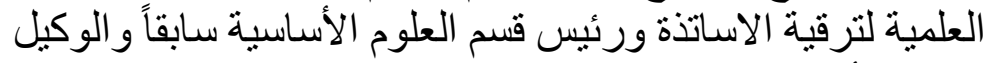
الأسبق بكلية التربية للطفولة المبكرة - جامعة القاهرة

مقدمة البحث:

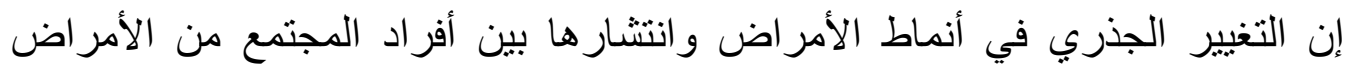

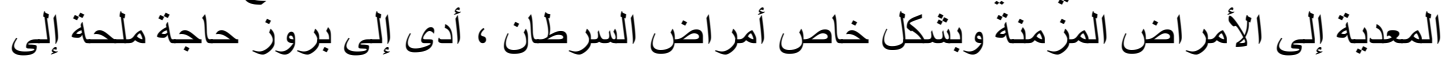

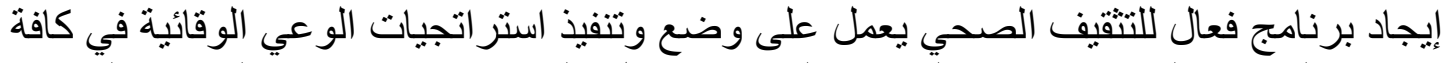

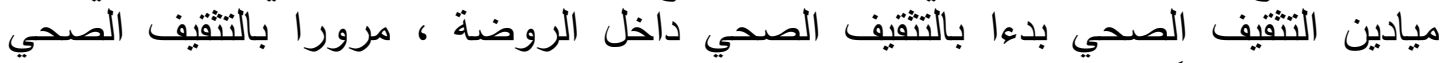

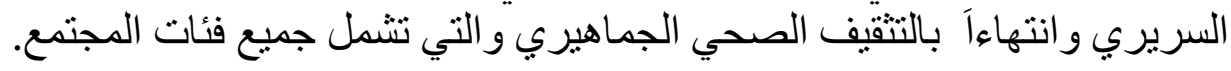

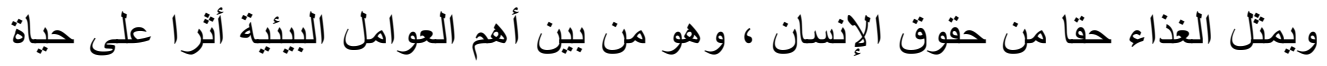

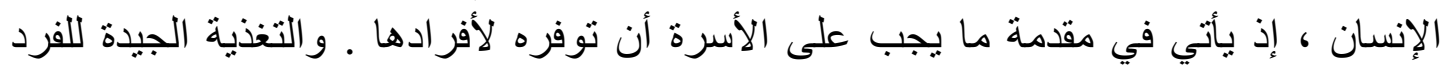

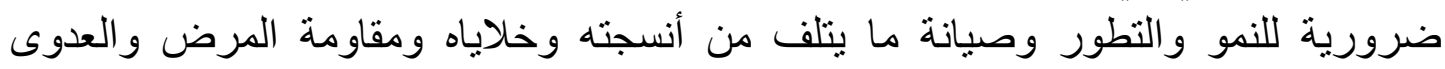
وارتفاع قدرته على العمل و الإنتاج.

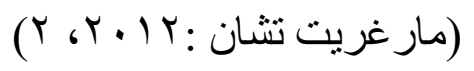

ولهذا فان التربية الصحية و الغذائية والاهتمام بالسلوك الصحي السليم للاطفال يعتبر

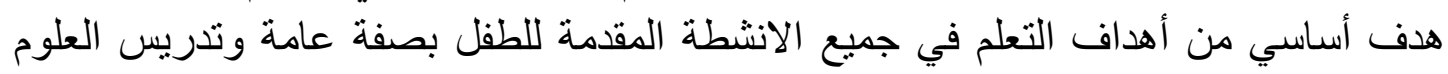

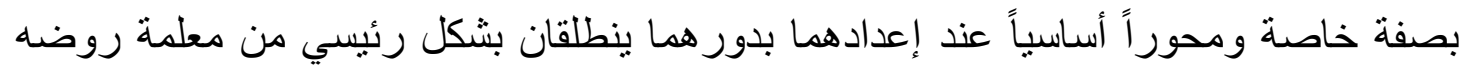

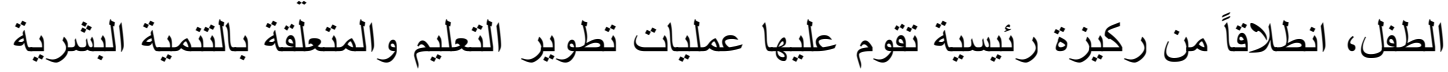

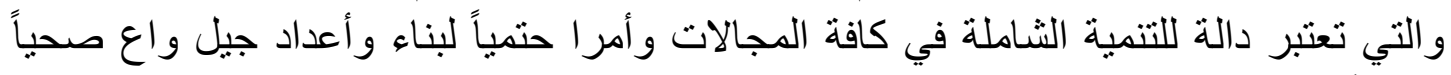

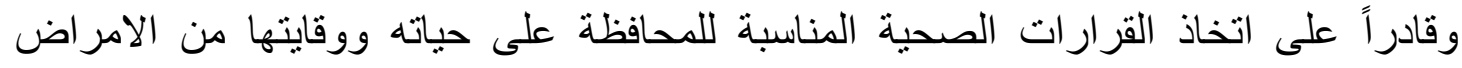

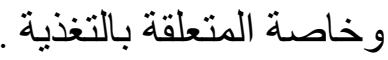

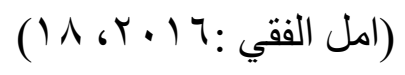

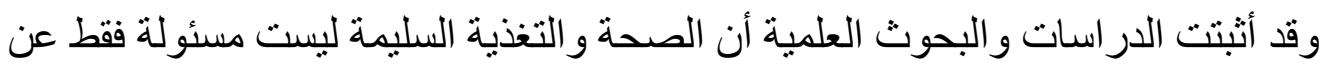

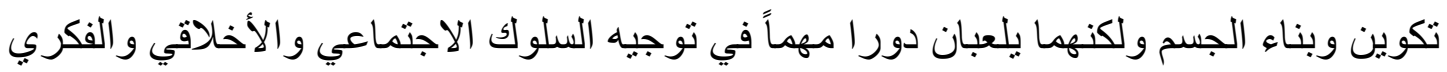

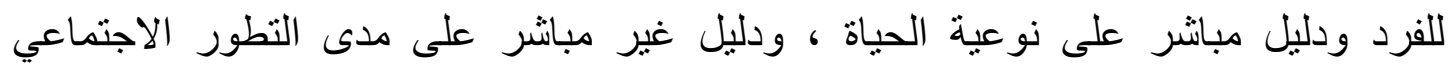

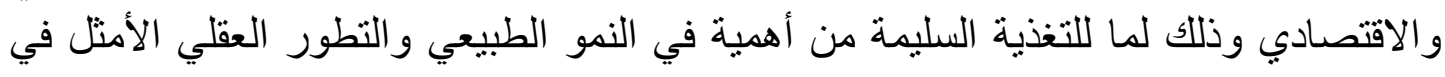
صحة المريض و السليم و الحفاظ على صحة جيدة خلال حياة الإنسان. 


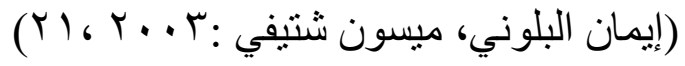

وخلال السنوات الأخيرة ثم الارتقاء بمفاهيم التثقيف الغذاء الصحي و الذي أصبح علما من

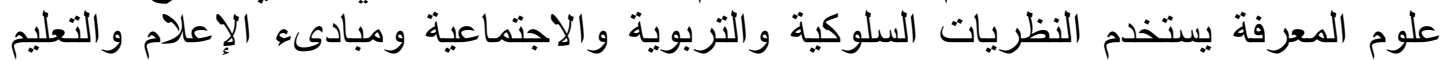

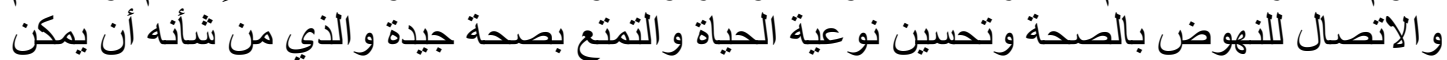

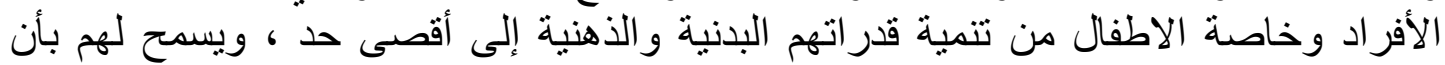

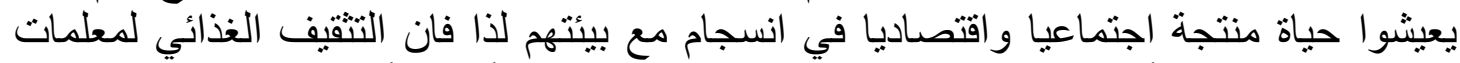

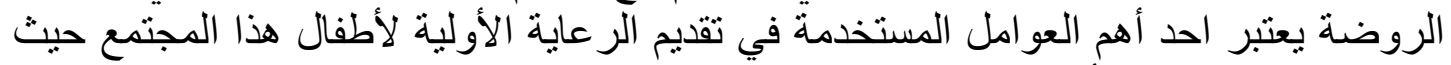

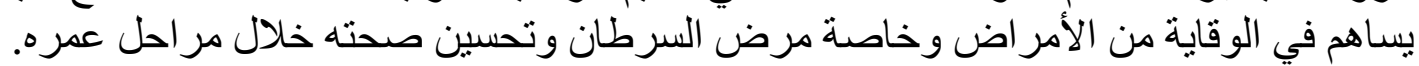

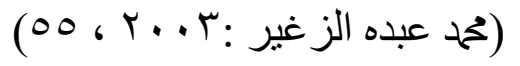

\section{مشكنة الدراسة:}

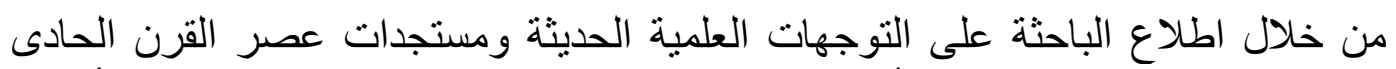

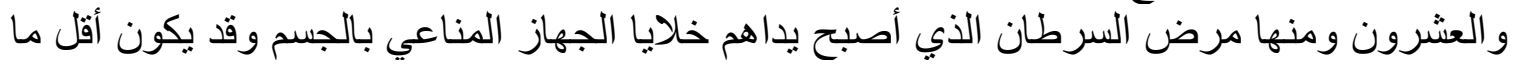

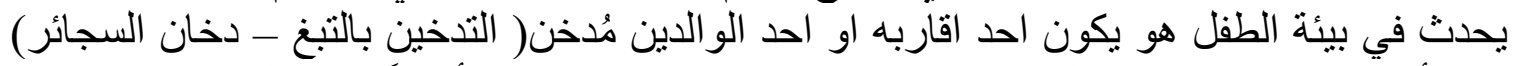

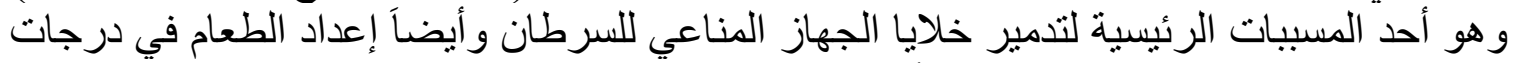

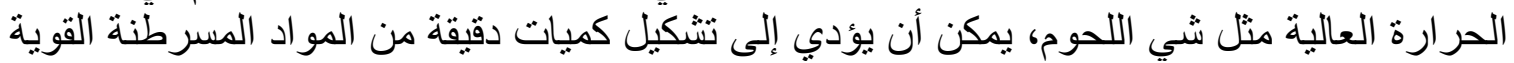

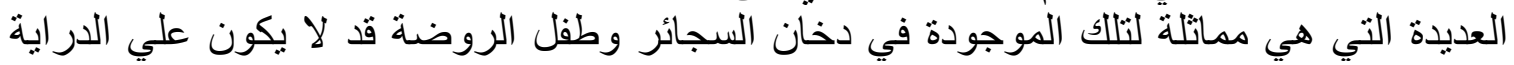

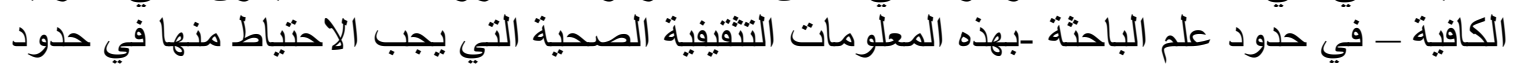
ما بستطيع.

وبحسب تقرير مجلة لانسيت لعلم الاورام و السرطانات لعام ب ا ـ ب ادلت بانه تحدث ثلث وفئ وفيات

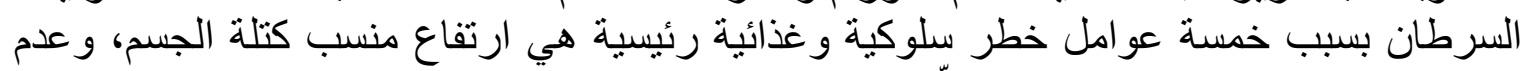

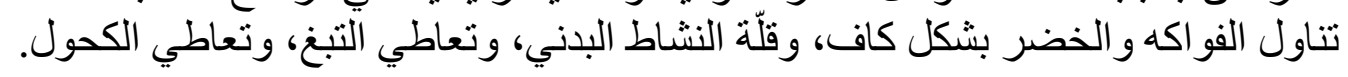

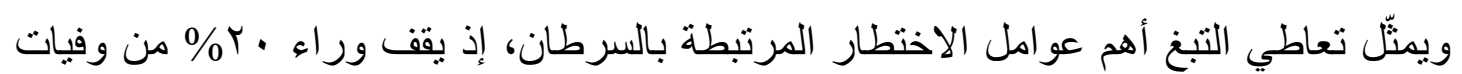

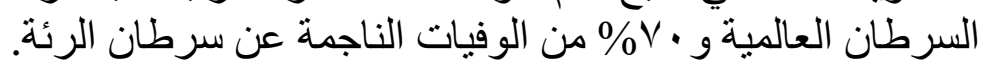

(de Martel C, Ferlay J, Franceschi S, et al : 2012)

ومن خلال تعامل الباحثة مع مجموعة من الاطفال اثناء تطبيقها لرسالة الماجستير وجدت الناله

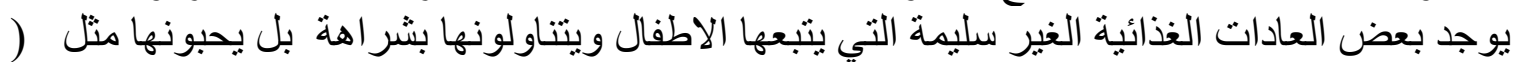

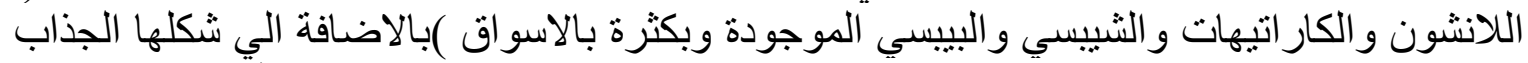

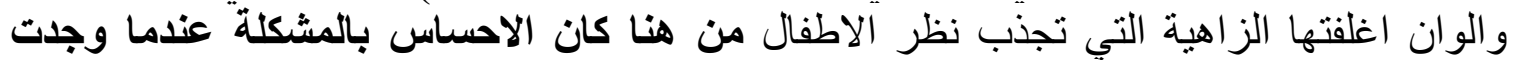

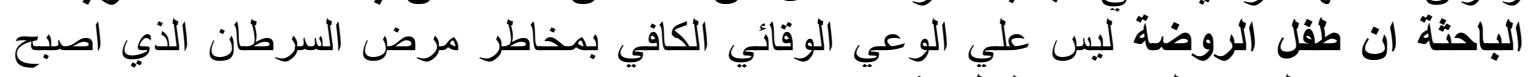

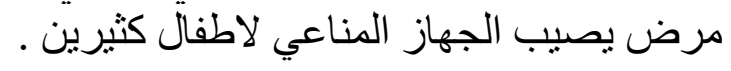

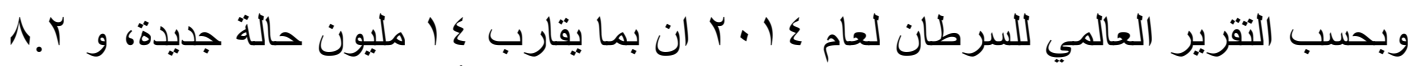

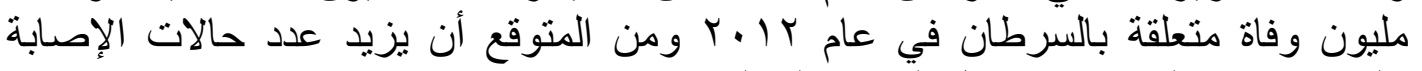
( World Cancer Reports 2014)

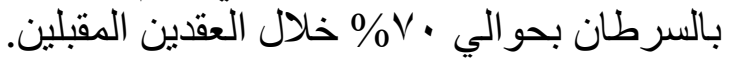

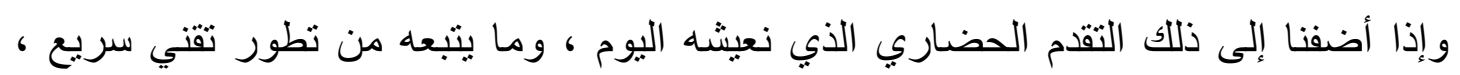

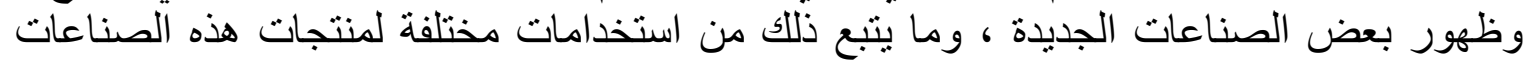

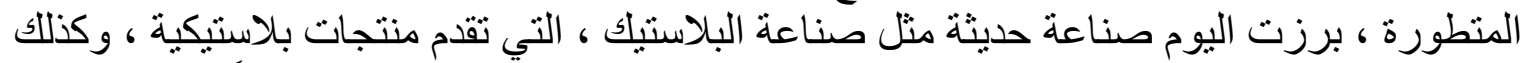
الأكواب والأطباق البلاستيكية ، التي أصبحت تستخدم اليوم بكميات كبيرة جداً لحفظ اللحوم 


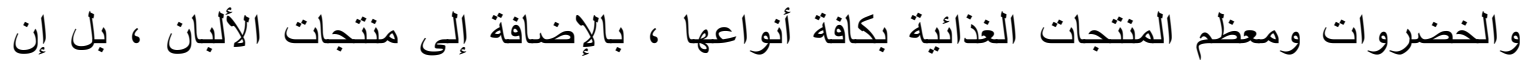

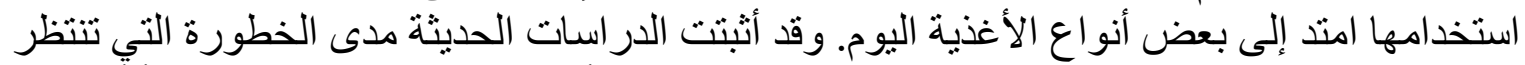

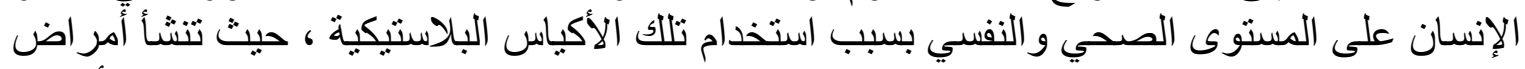

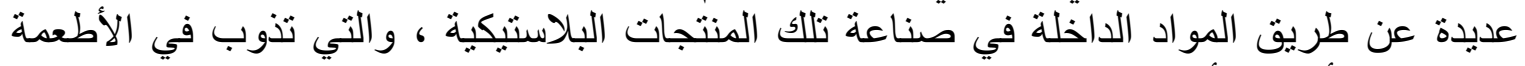

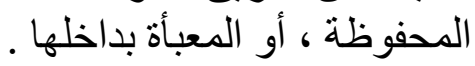

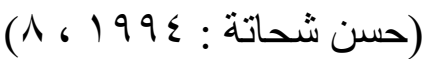

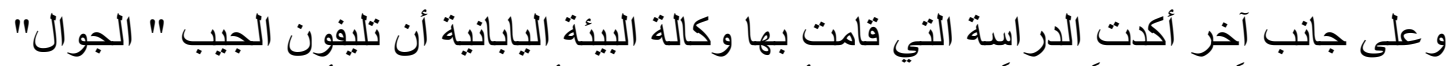

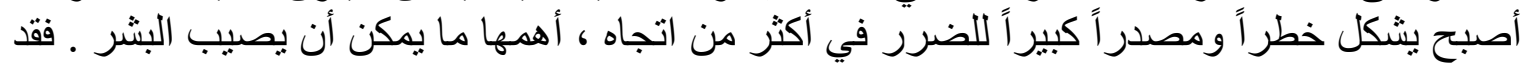

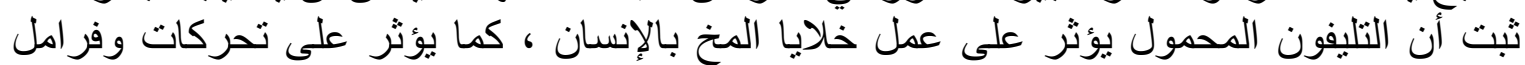

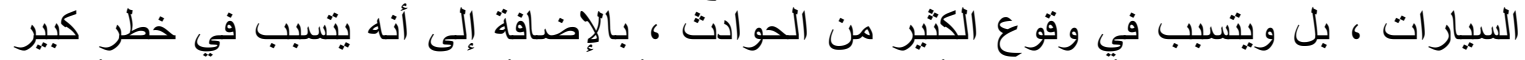

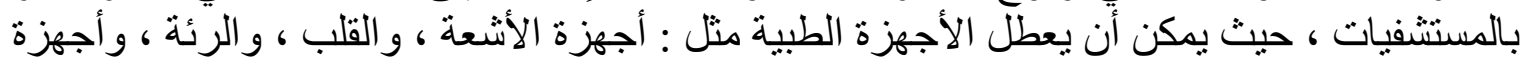

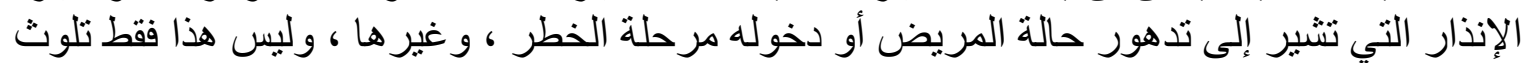

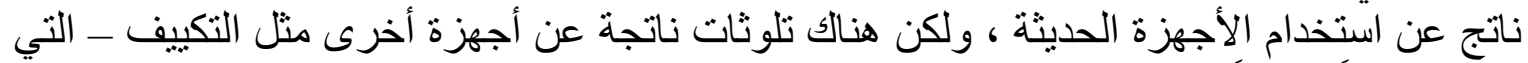

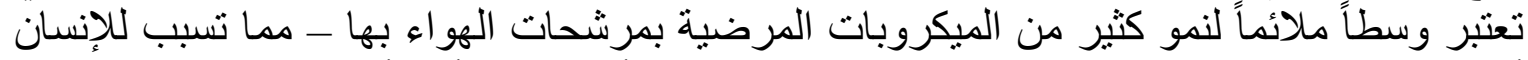

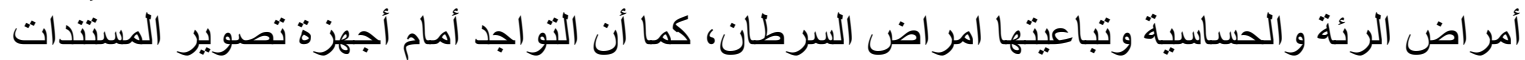

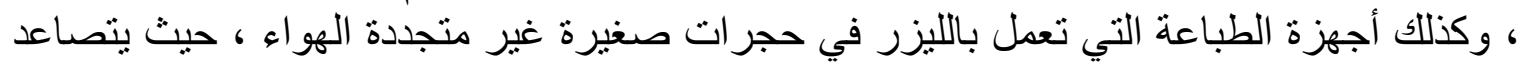

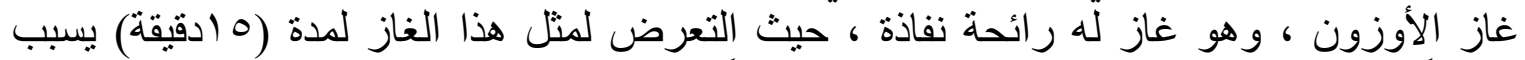

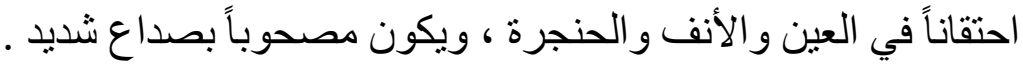

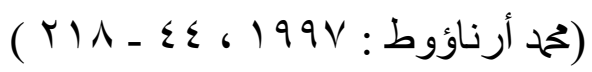

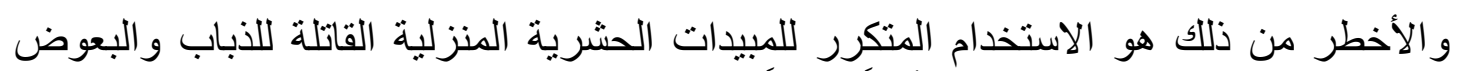

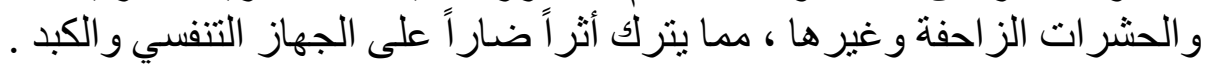

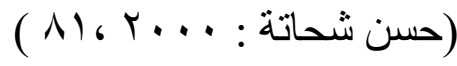

Abed El-Latif, F \& El- Grwany, ) فقد أثبتت در اسة فاتن عبد اللطيف وهالة الجرواني

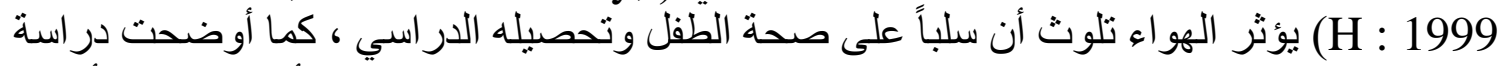

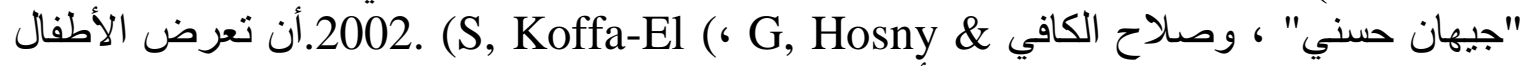

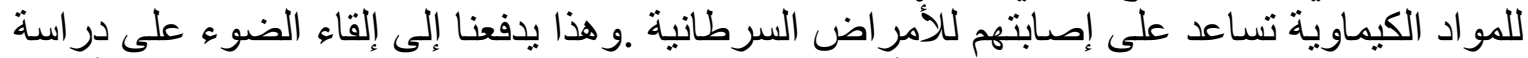

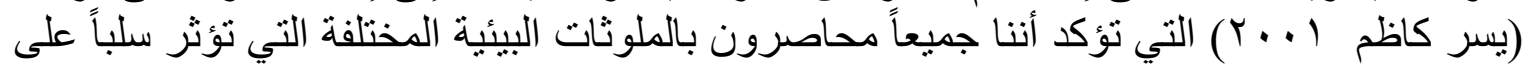

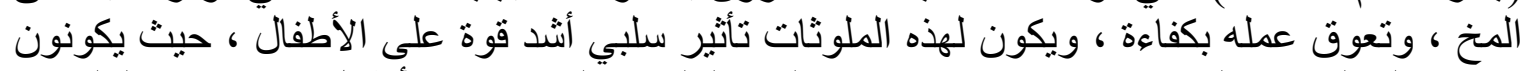

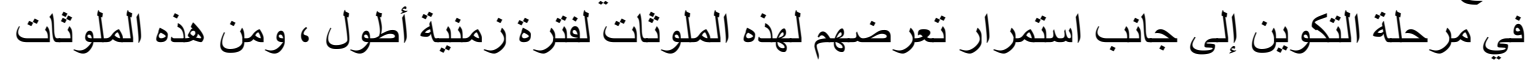

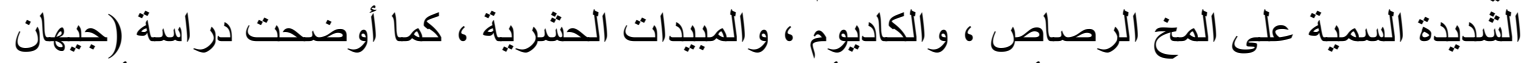

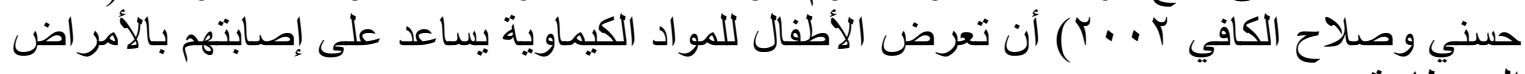
السرطانية.

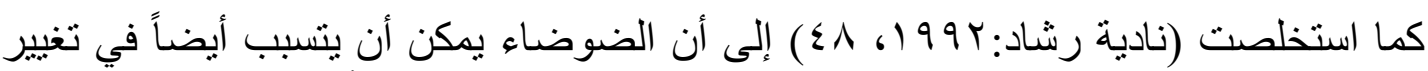

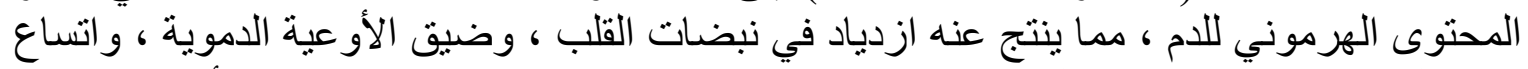

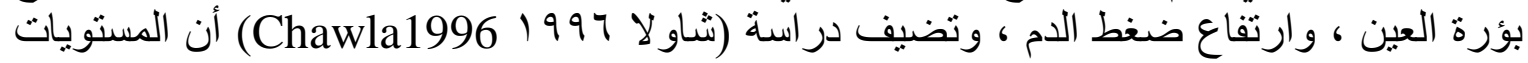

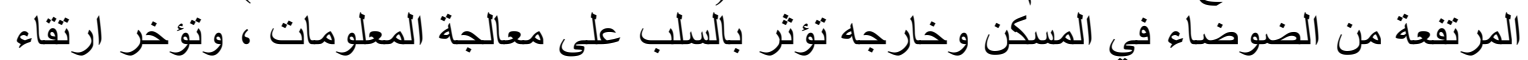

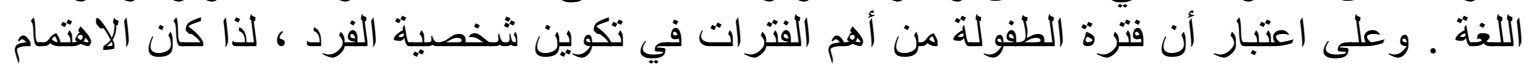

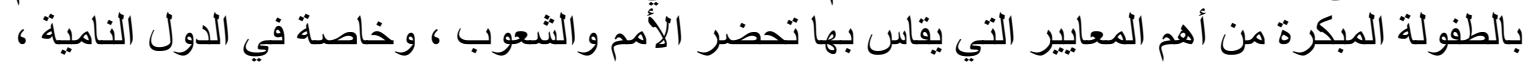

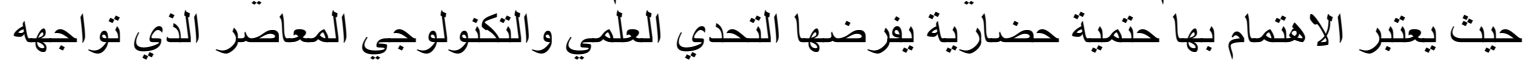




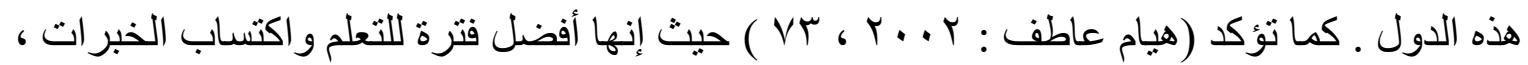

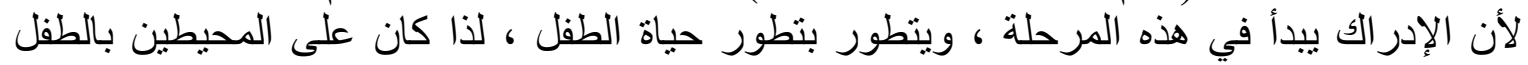

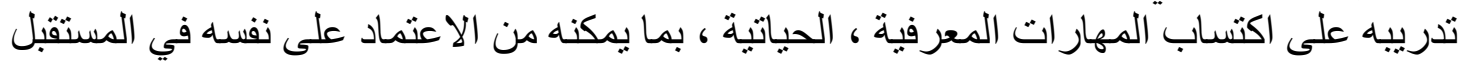

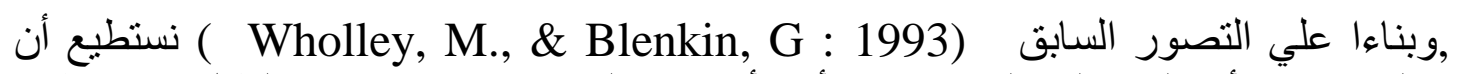

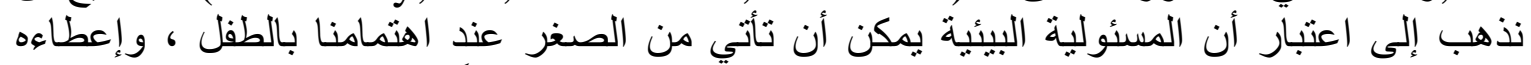

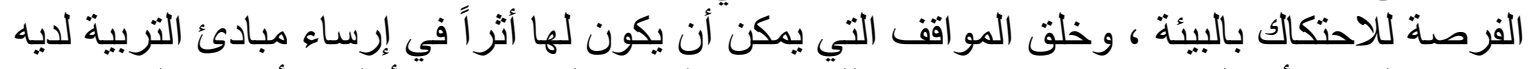

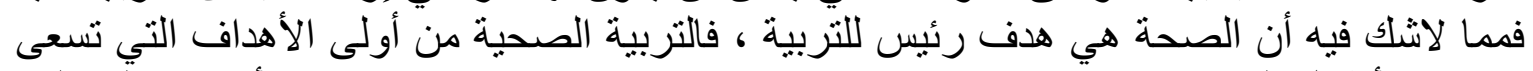

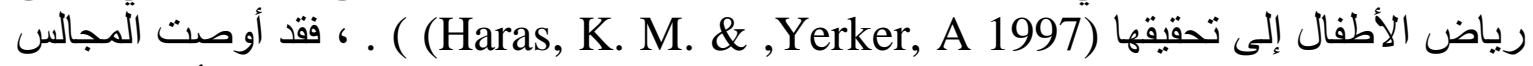

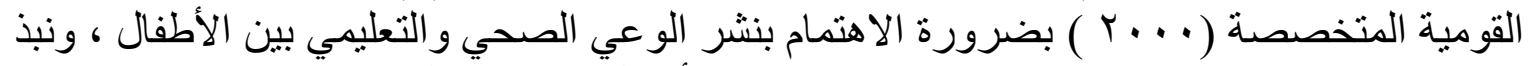

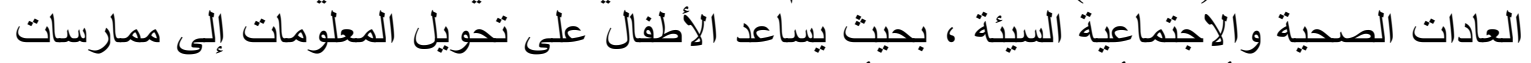

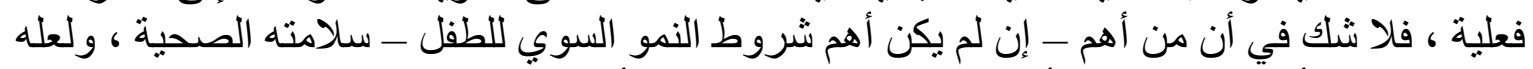

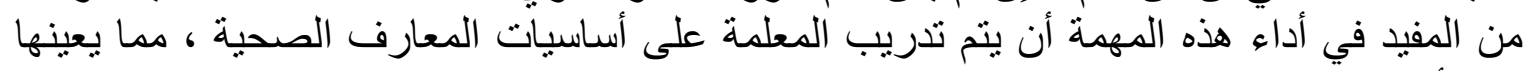

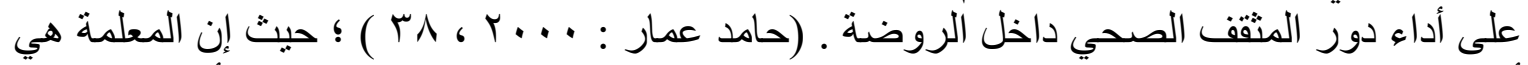

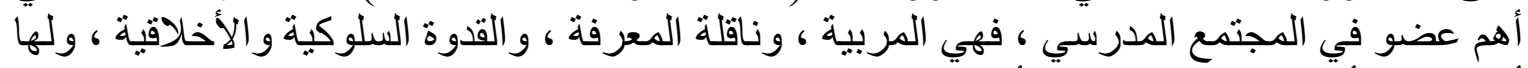

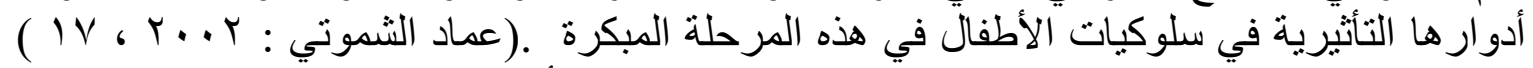

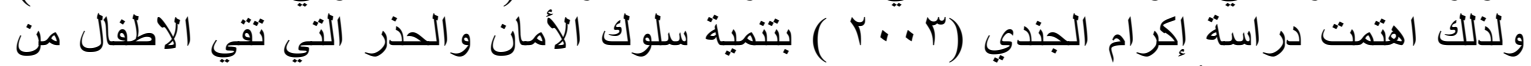

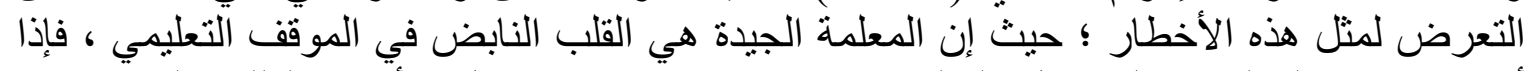

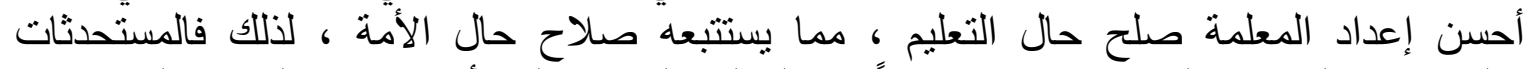

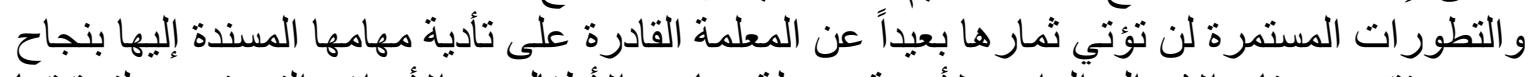

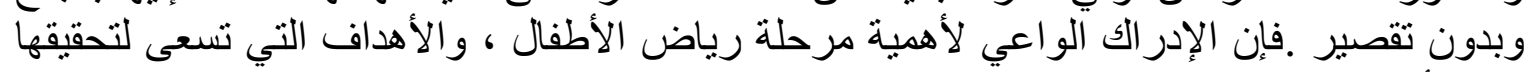

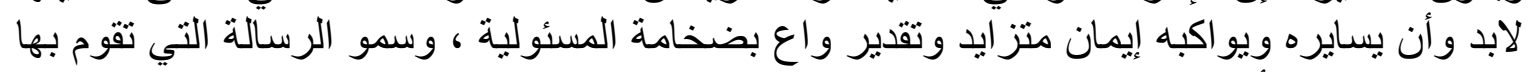

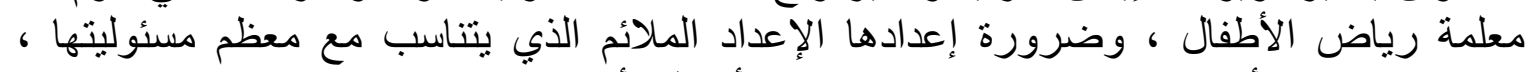

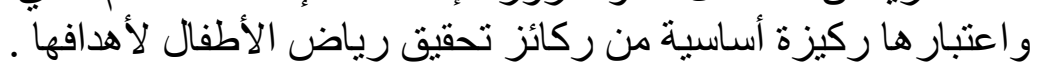

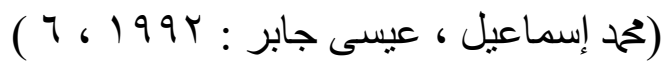

حيث تلعب معلمة رياض الأطفال دوراً رئيساً في تحمل الجزء الأكبر في الرعاية الصحية

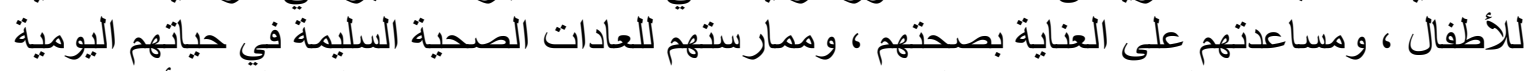

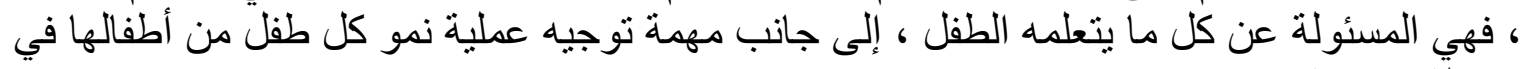
مرحلة حساسة من حياتهر.

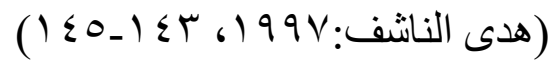

ومن خلال الاطلاع علي بعض الدراسات السابقة التي أجريت في هذا المجال لايوجد رسـالة

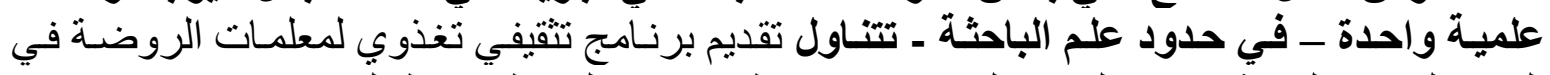

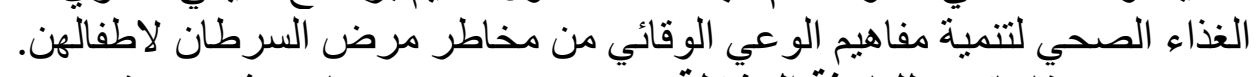

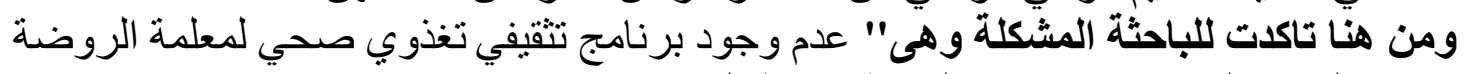

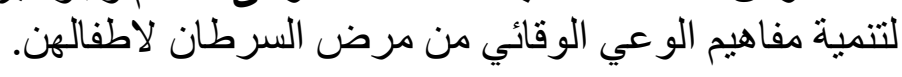
هذا ويمكن صياغة مشكلة البحث في التساؤلات التالية: أسئلة البحث ' . ما مفاهيم الوعي الوقائي الو اجب تنميتها لدي طفل الروضة؟ 


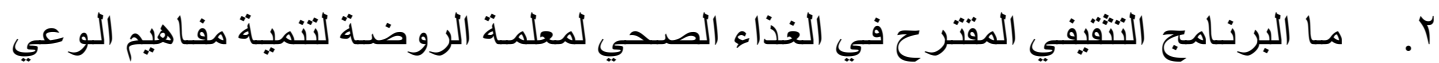

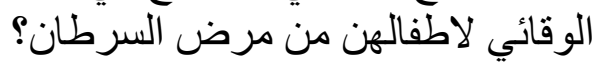

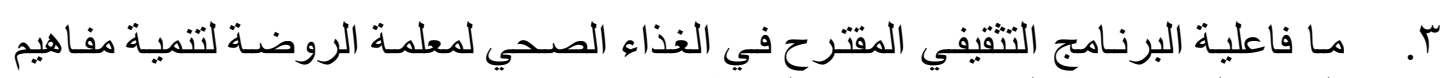

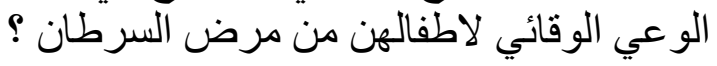

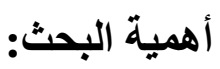

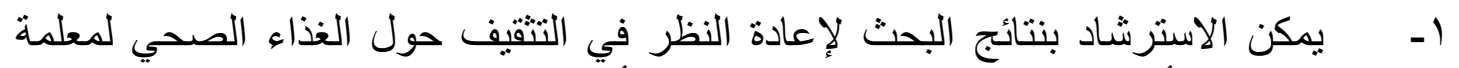

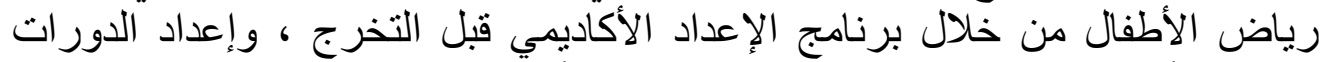

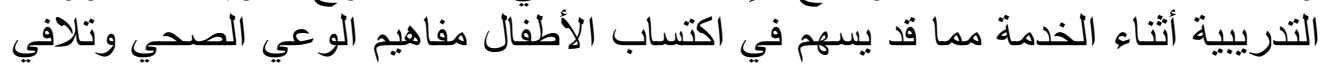
مخاطر الاصنابة بمرض الناء السرطة مدان. r- يلقي البحث الحالي الضوء علي الهم مسببات مرض السرطان لدي الاطفال وتلافيها من

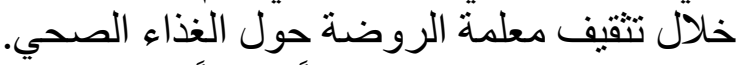

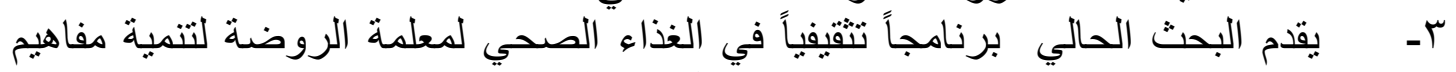

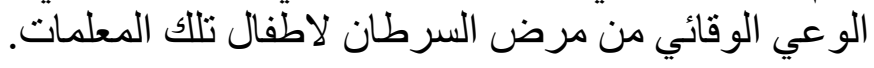

أهداف البحث : 2 - 2

$$
\text { ا . تحديد مفاهيم الوعي الوقائي من مرض السرطان. }
$$

ץ. تصميم برنامج تثقيفي في الغذاء الصحي لمعلمة الروضة لتنمية مفاهيم الوعي الوقائي من مرض السرطان لَأطفالهن.

ץ. تطبيق البرنامج التثقيفي المقترح في الغذاء الصحي لمعلمة الروضة لتنمية مفاهيم

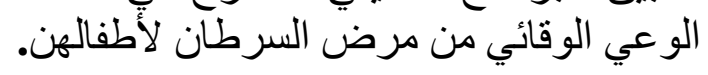

ع. قياس فاعلية البرنامج المقترح في الغذاء الصحي لمعلمة الروضة لتنمية مفاهيم الوعي

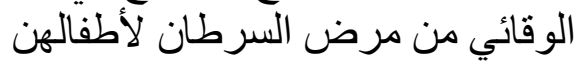

حدود الاراسةة: - ماري

• الحدود البشرية : يقتصر البحث الحالي علي • ب معلمة من معلمات الروضة.

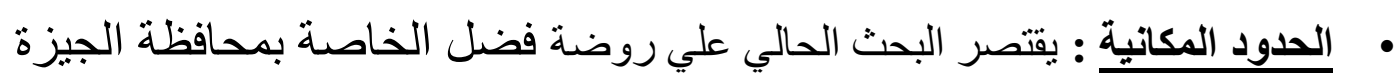

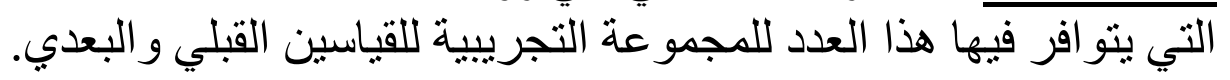

• الحدود الزمنية : يقتصر تطبيق البرنامج علي ثلاثة اشهر بمعدل ع ايام في الاسبوع ، ويستغرق تدريب اليوم الو احد (ساعتين) للمعلمتات.

منهج البحث:

إستخدمت الباحثة في البحث الحالي المنهج التجريبي وذللك باستخدام التصميم ذو المجموعتين

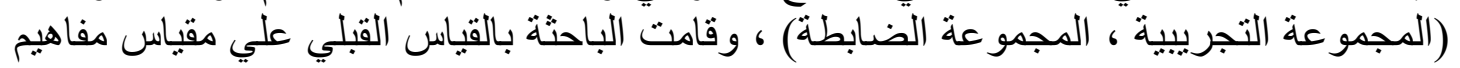

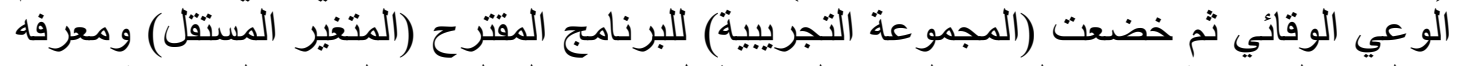

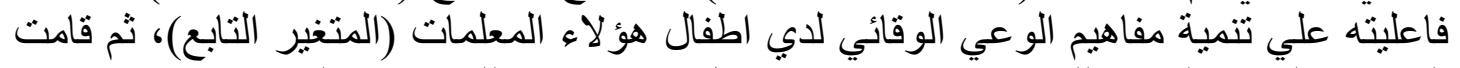

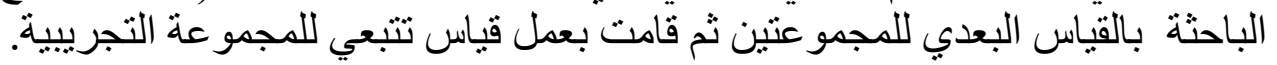




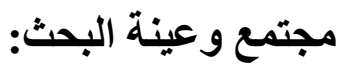

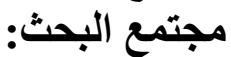

اثتنمل علي • أب معلمة من معلمات رياض الأطفال العاملين بالمدارس الحكومية وقد اختيرت العينة بصورة عثنو ائية.

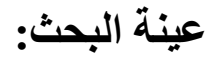

تكونت عبنة البحث من ـ 7 معلمة من معلمات الروضة مدرسة حلو ان الابندائية المشتركة التابعة لادارة القاهرة التعليمية بمدينة القاهرة.

\section{مصطلحات البحث}

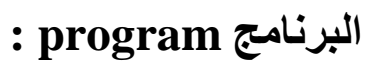

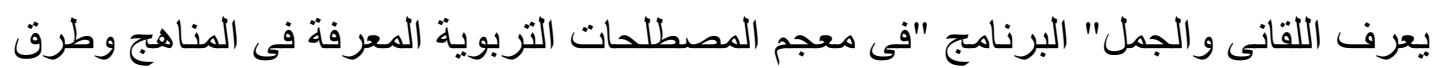

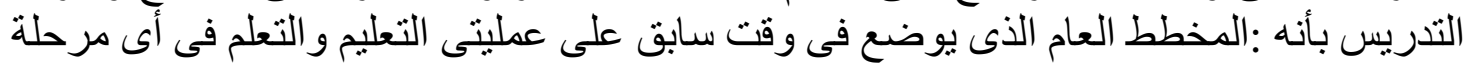

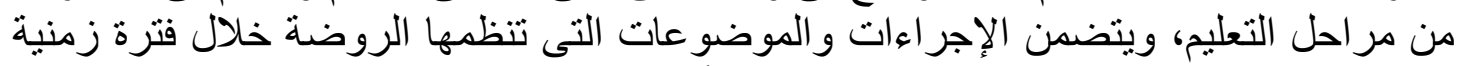

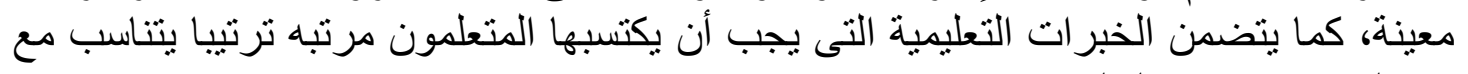

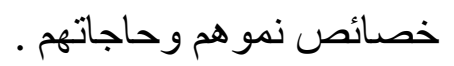

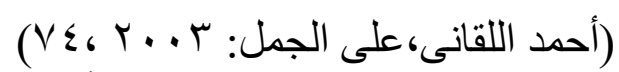

يعرف حسن شحاته وزينب النجار" البرنامج "فى معجم المصطلحات التربوية و النفسية بأنه :

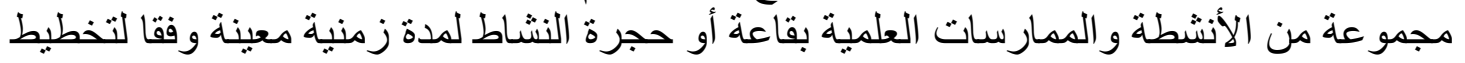

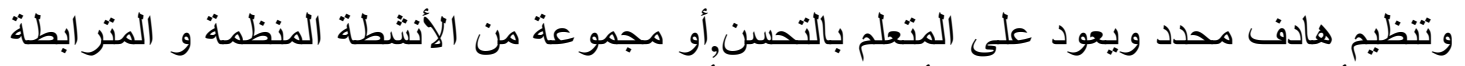

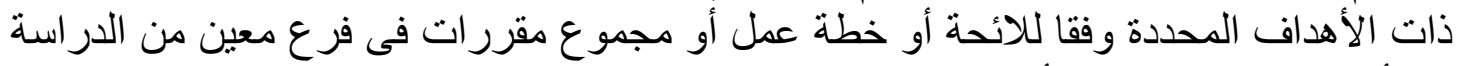

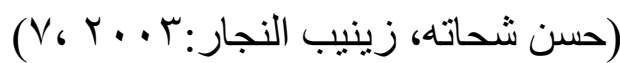
وله أنشطة متتو عة لتحقيق أهداف محددة .

كما يعرف" البرنامج "باتهه : مجموعة من الخططو الانشطة المتر ابطة المتكاملة الثشاملة لمو اقف تربوية تتركز حول الطفل بتوجيه معلمة متخصصة لتهن لتحقيق الاهداف المنشودة في بيئة تربوية ممتعة. و ايضا يعرف" البرنامج "بانه: مجمو عة من الانشطة و الالعاب و الممارسات العملية التى يقوم التئه

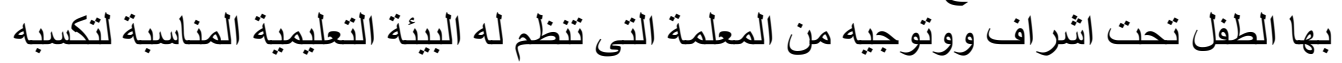

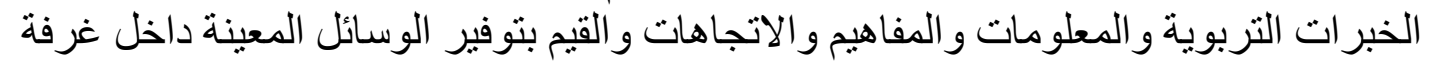

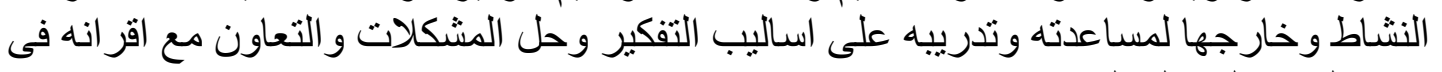

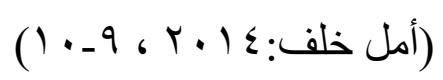

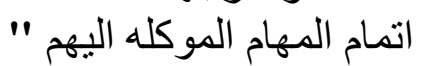

وتعرف الباحثة البرنامج إجر ائياً بإنه :مجمو عة من الأهداف و الخطو ات وات و الإجر اءوات و الأدورات

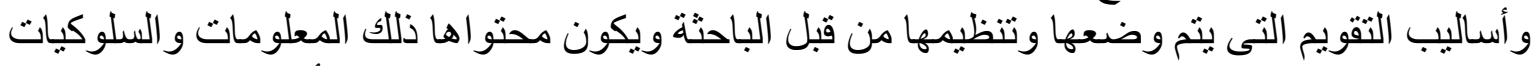

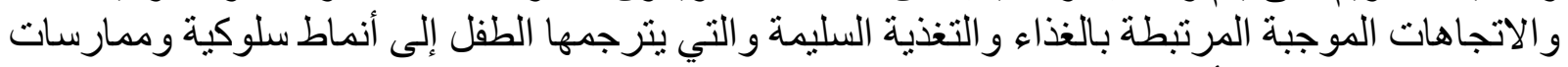

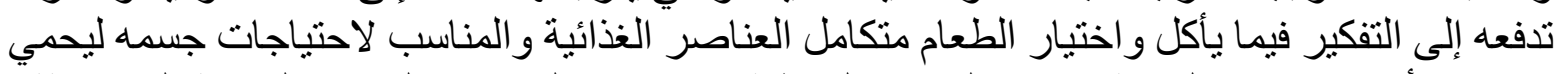

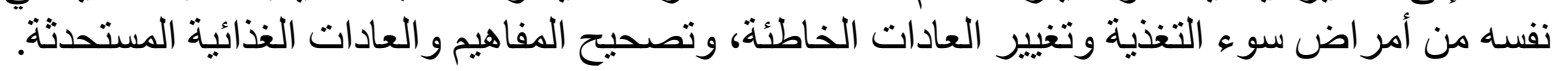
برنامج تثقيفي تغذوي صحي (التثقيف الصحي في الذذاء) :

مجمو عة من الخبر ات و الأنشطة التي تتضمن المعلومات و المعارف التخذوية و الصحية التي تقدم 
لمعلمات الروضة ، بهدف إكسابهم تللك المعلومات و المعارف وترجمتها إلى ممارسات يومية

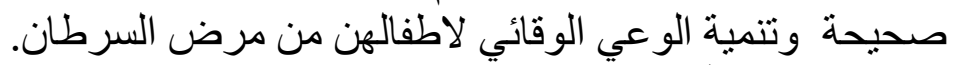

معلمات الروضة:

تقوم بتربية الطفل في مرحلة الروضة وتسعى إلى تحقيق الأهداف التربوية التي يتطلبها

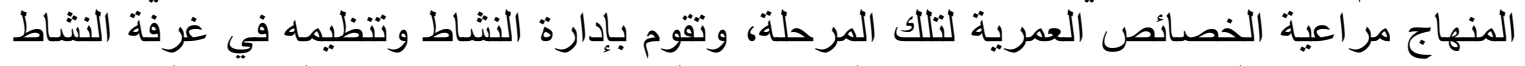

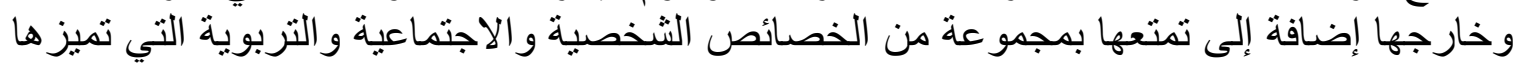

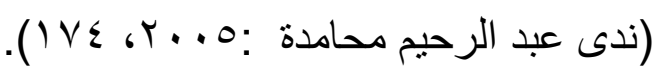

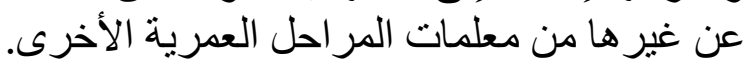

\section{مفاهيم الوعي الوقائي من مرض السرطان:}

هي مفاهيم خاصة بمعرفة و إدر الك و إحساس المعلمة بأهمية الغذاء و التغذية السليمة و علاقتها

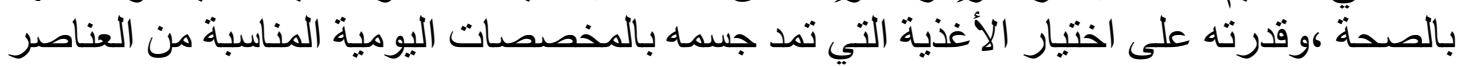

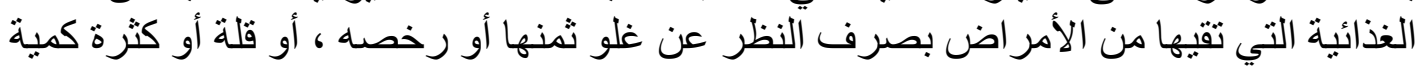

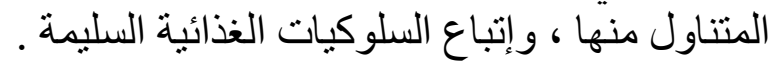

$$
\text { فروض الاراسة: }
$$

ا ـ لا توجد فروق ذات دلالة احصائية بين متوسطات درجات معلمات (المجموعة التجريبية) ومتوسطات

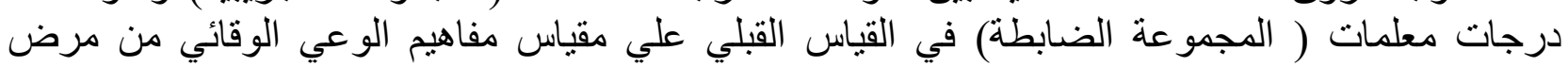
السرطان.

ץ- توجد فروق ذات دلالة احصائية بين متوسطات درجات معلمات (المجمو عة التجريبية ) بين القياسين القبلي

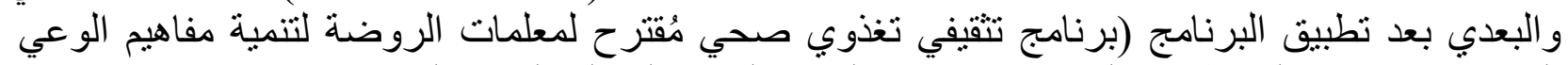
الوقائي من مرض السرطان) علي مقياس مفاهيم الوعي الوقائي لصني لصالح القياس البعدي. بـ لا توجد فروق ذات دلالة احصائية بين متوسطات درجات معلمات (المجموعة الضابطة ) بين القياسين

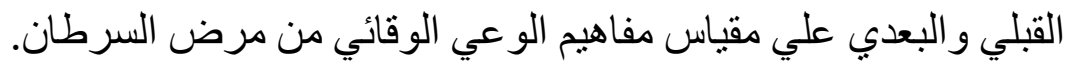

عـ توجد فروق ذات دلالة احصائية بين متوسطات درجات معلمات (المجموعة التجريبية ) و منوسطات درجات معلمات (المجمو عة الضابطة ) في القياس البعدي علي مقياس مفاهيم الوعي الوقائي لصالح المجموعة التجريبية.

الاطار النظري ودراسات سابقة:

مفهوم الثقافة الصحية ويقصد به إلمام معلمات الروضة المافة بالمعلومات و الحقائق الصحية وأيضا إحساسهم بالمسئولية نحو صحتهم وصحة غيرهم، وفي هذا الإطار بعتبر الوعي الصحي هو الممارسة عن قصدٍ نتيجة الفهم و الإقناع.

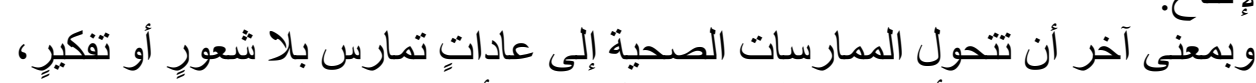

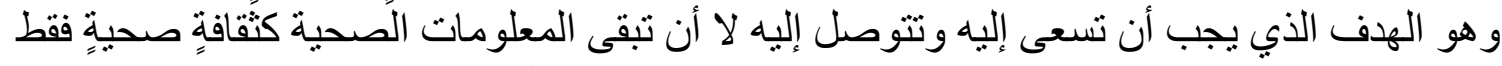

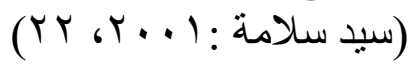




\section{التخذية الصحية وأثرها على مقومات الثخصية :}

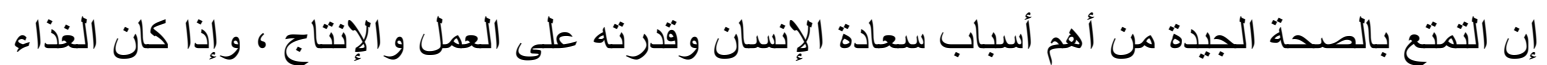

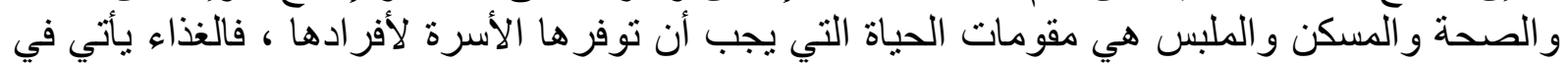

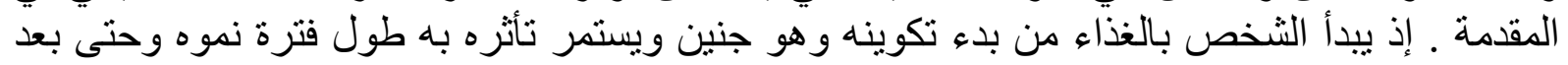

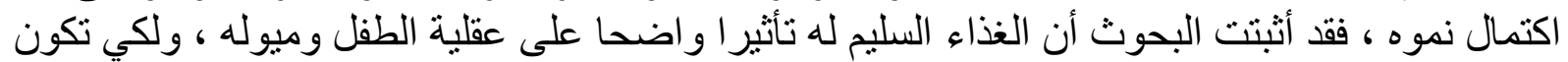

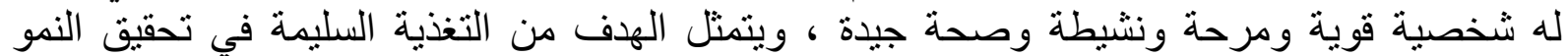

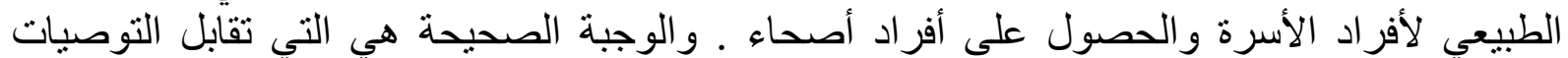

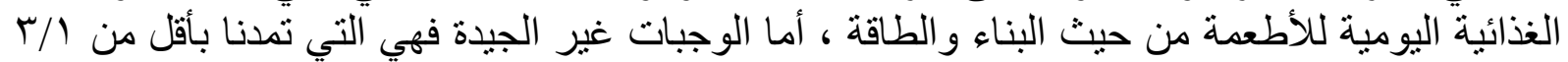

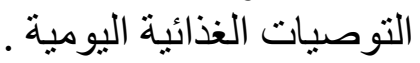

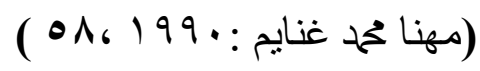

وتعرف التغذية السليمة بأنها تناول الفرد أغذية تحتوي على كميات تكفي احتياجات جسمه من العناصر

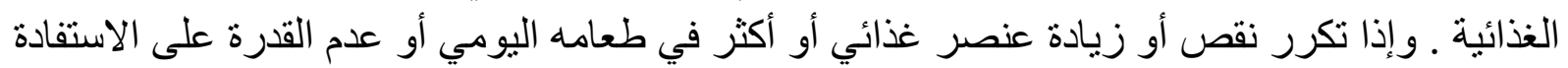

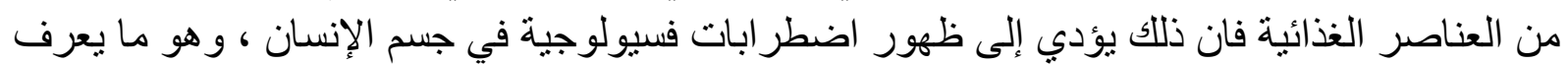

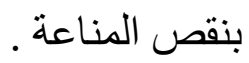

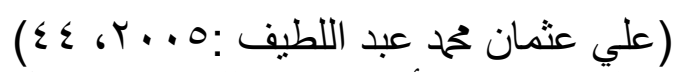

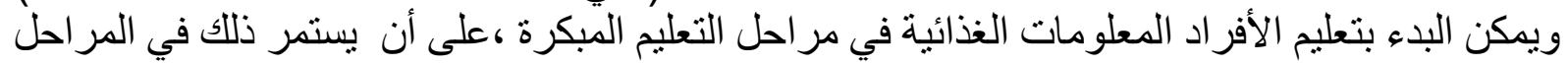

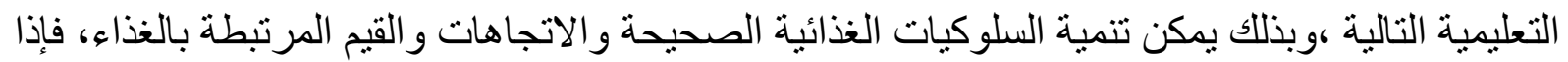

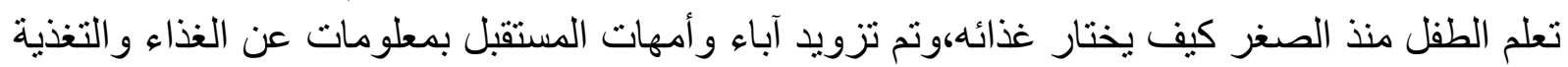

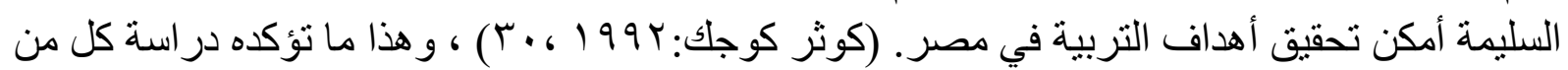

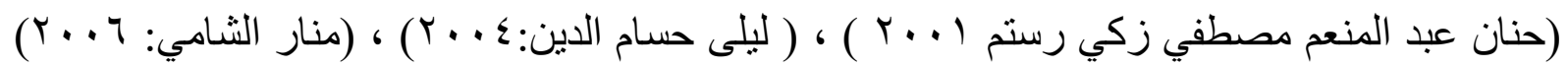

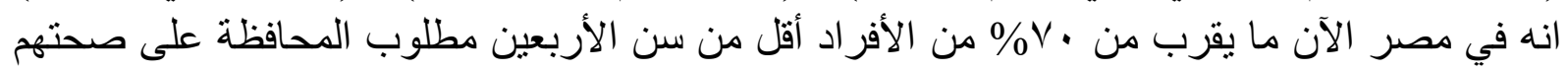

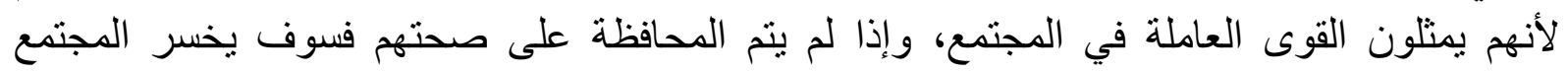

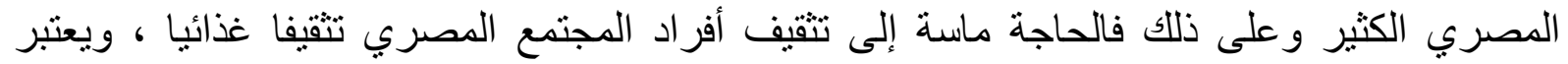

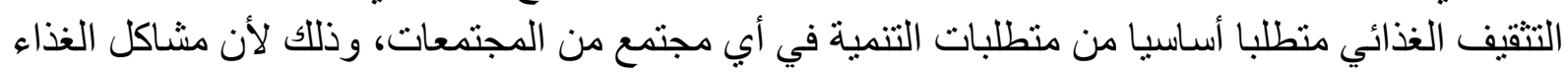

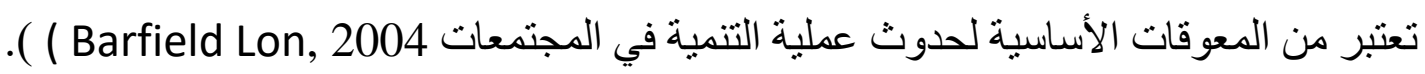

الثقافة الغذائية والعادات الغذائية :

وبالرغم من أن الغذاء يحتوي على العديد من العناصر الغذائية اللازمة لجسم الإنسان، بأخذ الجسم منها احتباجاته

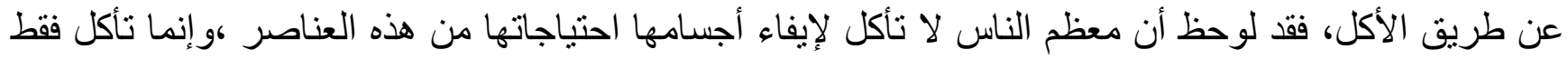

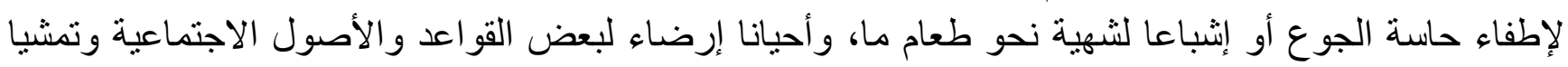
معها.

(Walter C. Willett and Meir J. Stampfer :2003)

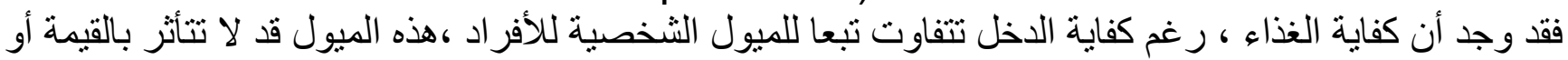

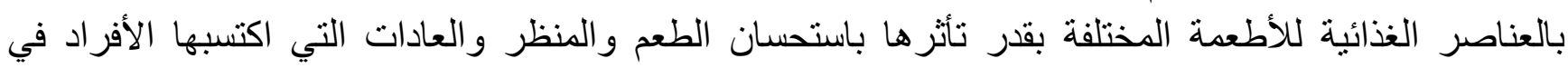

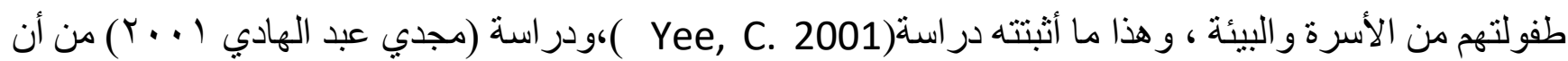

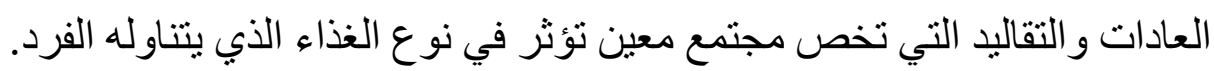




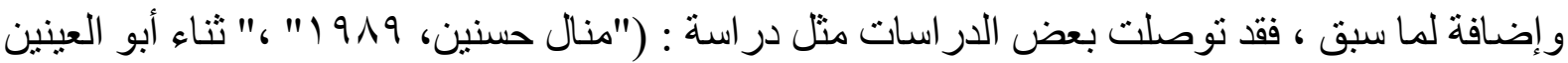

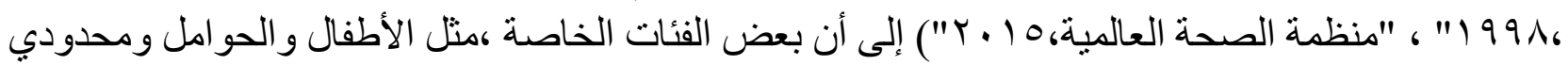

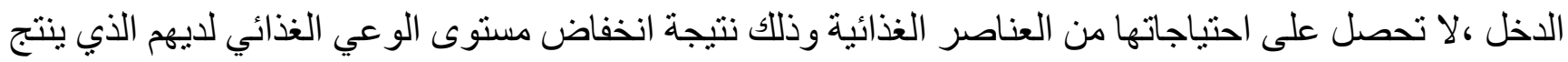

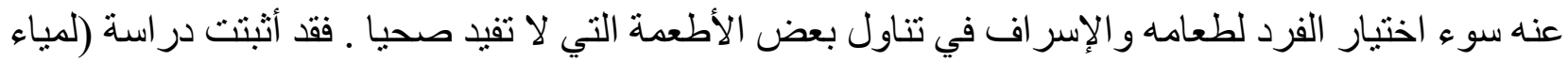

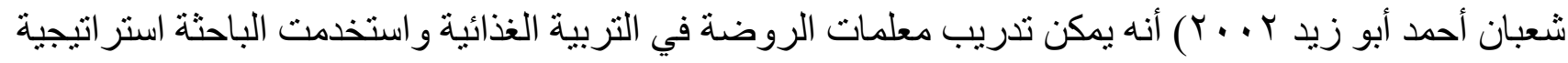

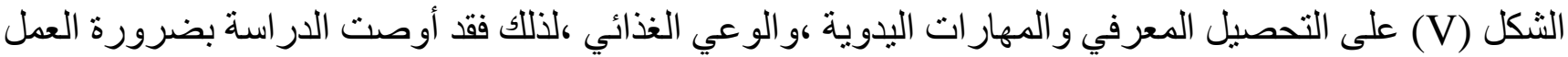

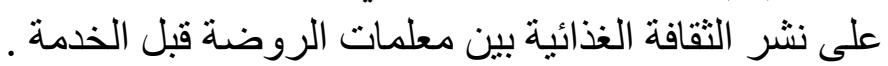
وتتحقق التربية الصحية عن طريق-: 1 ـتزويد الفرد بالمعلومات و الحقائق الصحية الوظيفية التي يستطيع أن بستفيد منها

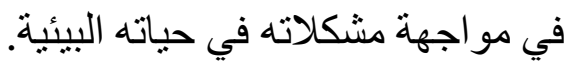
ب ـتكوين العادات الصحية لمساعدة الفرد على السلوك الصحي السليم بما يحقق له الصحة الثخصية. r ـاكتساب الفرد المعارف و المهار ات الصحية الأساسية اللازمة له و لا يمكن الاستغناء عنها في الحياة اليومية للفرد كتعلم الإسعافات الأولية و الرعاية عند المرض. ع ـتكوين الإتجاهات الصحية السليمة حتى يتحرر الفرد من الخرافات الثائعة في المجتمع. ه - إكساب الفرد طريقة التفكير السليم التي تقوم على الملاحظة الاقيقة و عدم تقبل الآر اءو الأحكام قبل التأكد من دليل صحتها.

( Carter, L, 1998:17)

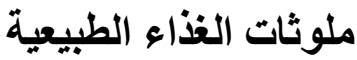

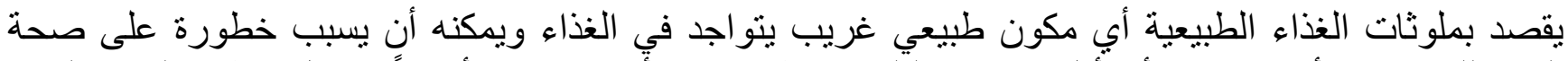

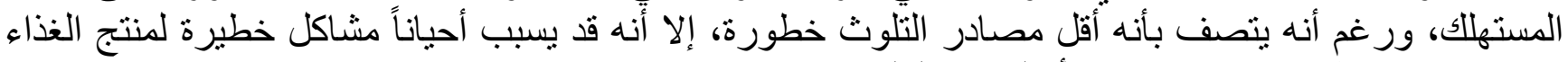

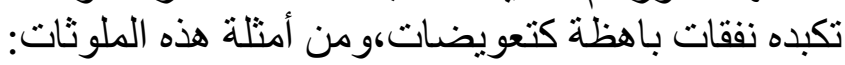

ملوثات تصل إلى الغذاء أثناء النمو و الحصاد، كالحجارة و الأتربة و المعادن و الحشر ات ولئات وبقاياها.

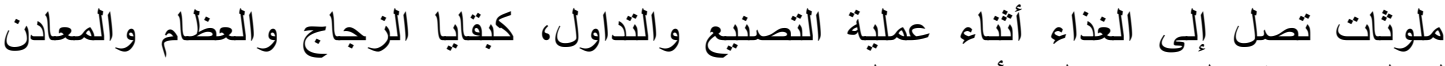

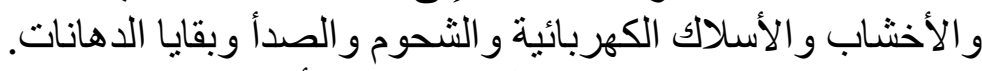
ملوثات تصل إلى الغذاء أثناء عملية التعبئة والتوزيع، كالحشرات والثيات والخيوط و الثشعر والأحجار

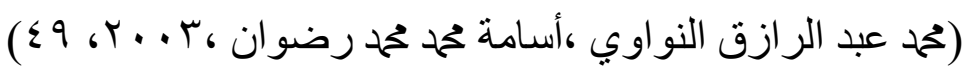


الملوثات الكيميائية للغذاء

يقصد بها الملوثات الغذائية غير الجرثومية، فأي مادة كيميائية قد تصل إلى الغذاء أثناء عملية الإنتاج أو التداول أو قد تضاف إلى الغذاء بغرض حفظه، أو قد تتو اجد طبيعياً في الغذاء، و التي تمثل خطورة على صحة صلى مستهرلك الغذاء في حالة استهلاكه.

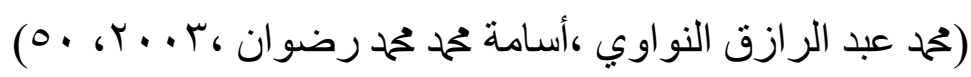

\section{ملوثات كيميائية زراعية}

أي المواد الكيميائية التي تستخدم في زيادة الإنتاج النباتي والحبو اني والسمكي وبقاياها، والتي تتصف بتأتيثر ضار

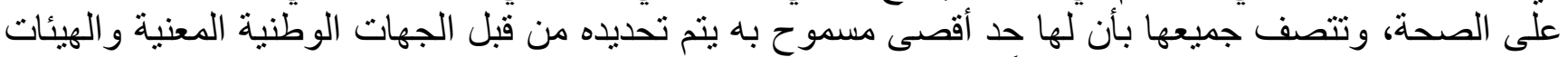

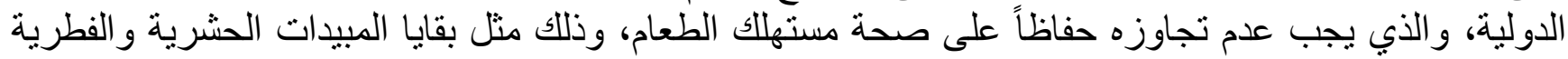

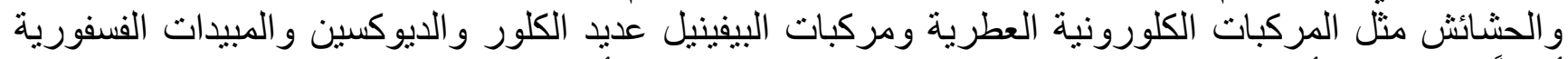

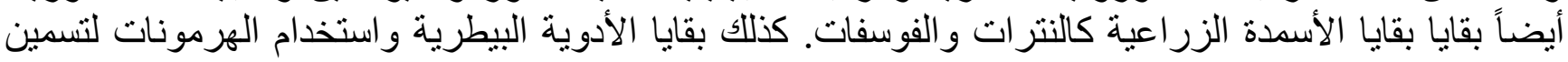
الدو اجن وتربية الثروة السمكية.

\section{( فيليب عطية (1) 199 (1)}

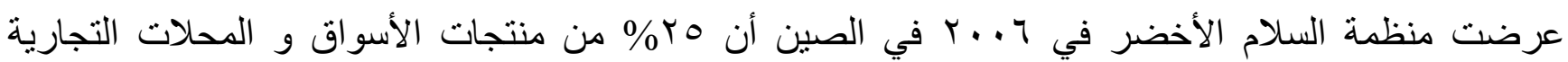

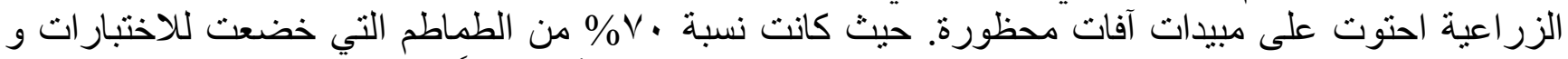

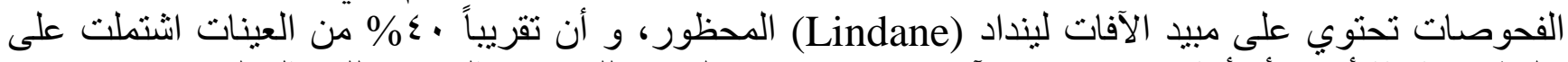

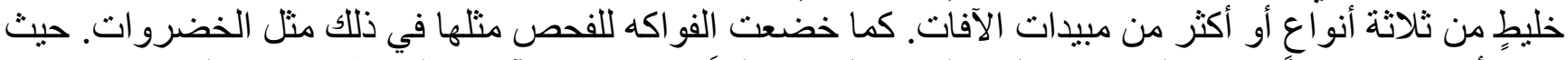

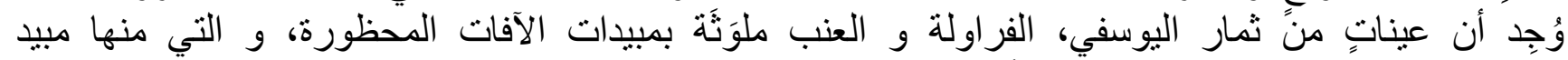
Methamidophos منظمة السلام الأخضر أنه لا تتو افر عملية ضبطو سيطرة شاملة على إنتاج الفو اكه في هونج كونج اعتبار أ من عام r...T

(Greenpeace Exposes Guangzhou Pesticide Contamination, 2006)

وفي فيتنام عام V . . r، انتشرت أخبار وجود الفورمالدهيد، وهو مادة مسرطنة وُجدت في طبق الخضار الوطني،

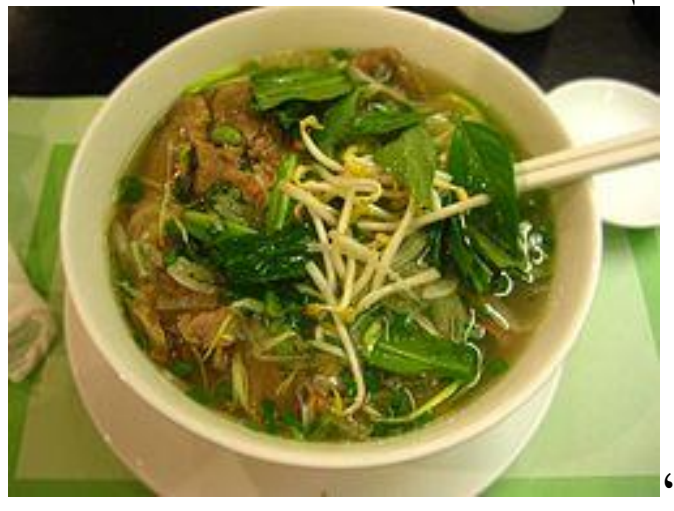

و الذي أثنار مخاوف من الطعام الفيتتامي. كما أنه وُجد أن الخضراوات والفواكه تحتوي على مبيدات الآفات

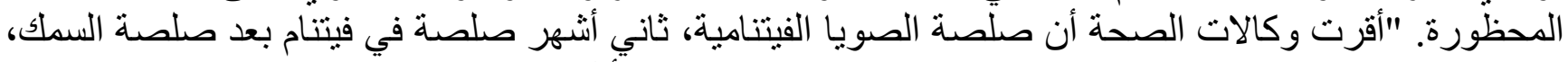

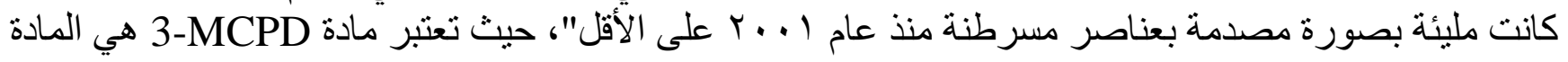


المسرطنة في الصلصات الآسيوية و مستقلبها هو 1,3-DCP، و التي مثلت مشكلة قائمة قبيل عام ، .. ب و المؤثرة على العدبد من القار ات.

(chemical veggies -- food scares hit Vietnam)

\section{ملوثات كيميائية صناعية}

تضم بقايا مو اد التنظيف و التطهير والزيوت والثحومات و السولار و الكيروسين والأمونيا والمبيدات الحشرية،

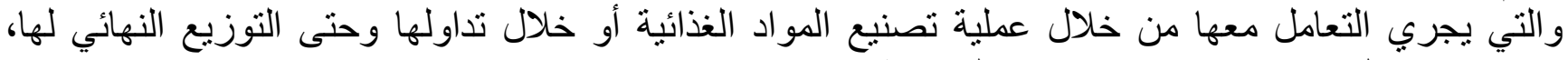
وتتصف هذه المو اد بسميتها في نركيز اتها المرتفعة.

فمثلاً في الهند، فقد وُجدَ أن المشروبات الغازية تلوثت بمعدلاتٍ عاليةٍٍ من مبيدات الآفات ومبيدات الحشرات، و التي

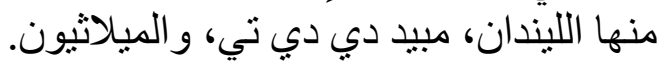

(Tribhu MRatta, 2008)

الملوثات الكيميائية المحتمل وجودها طيعياً فى الغذاع

ويقصد بها الملوثات السامة المحتمل وجودها طبيعياً في الغذاء وتتثنمل أساساً على المركبات الناتجة من عملية الأيض في الخلايا النباتية و الحيو انية.

\section{ملوثات الإضافات إلى المواد الغذائية}

ويقصد بها ما يضاف إلى المو اد الغذائية كالمو اد الحافظة لزيادة فترة الصلاحية، أو لتحسين خو اص الغذاء سواء في صورة محسنات طعم أو رائحة أو قو ام أو لون أو مستحلبات أو مثبتات الو لونات

(محمد عبد القادر الفقي 1999 19 107)

\section{ملوثات كيميائية سامة ناتجة عن عملية تصنيع المواد الغذائية}

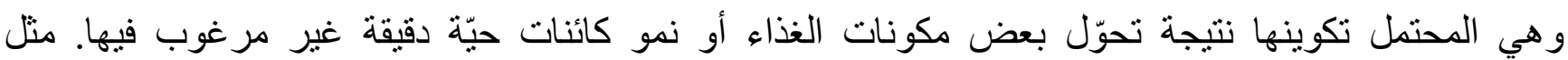

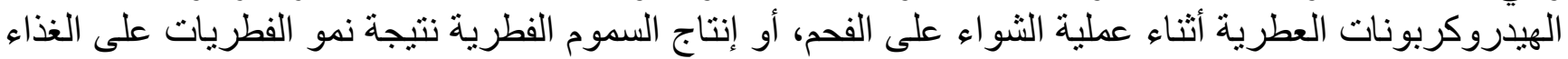
مثل الأوكر اتوكسين و الروبرونو كسين.

ملوثات المعادن الثقيلة

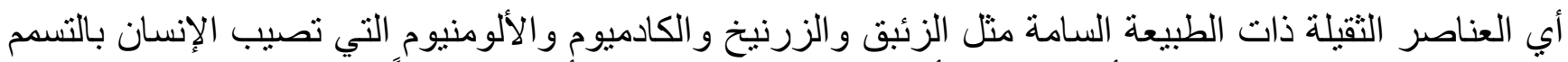

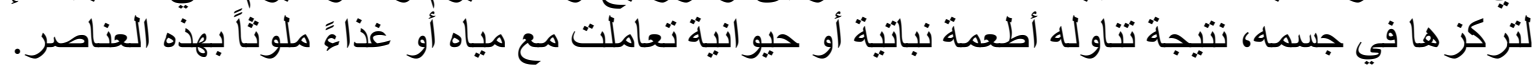

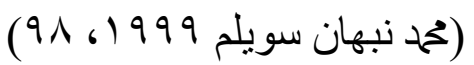




\section{ملوثات الغذاء الإشعاعية}

تم تطوير تقنية تشعيع الغذاء في السبعينات من القرن العشرين، وذلك من أجل زيادة فترة عرض ثمار الفاكهة

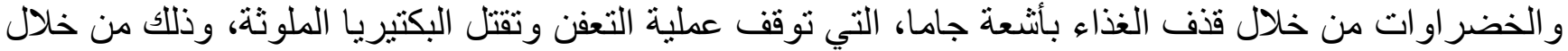

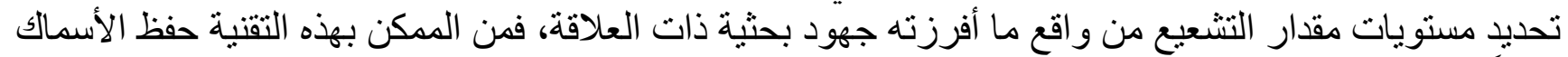

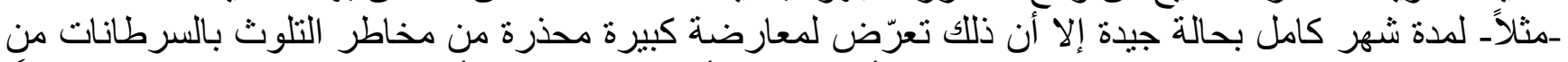

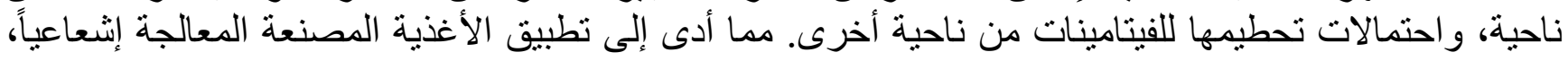

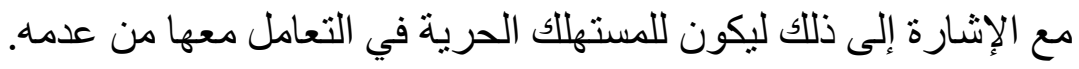

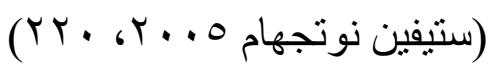

\section{الهندسة الوراثية والتلوث الغذائيى}

الهندسة الور اثية لها دور مهم في الحفاظ على التنوع الأحيائي على الأرض ـوقد وصل عدد أنواع النباتات المهندسة

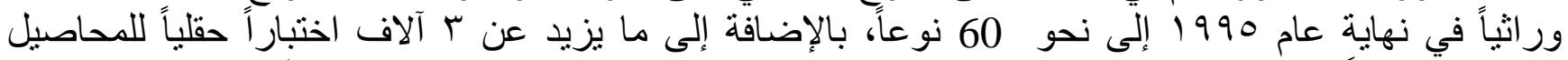

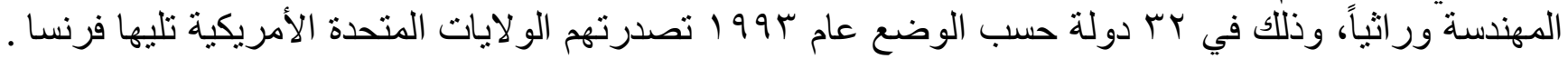

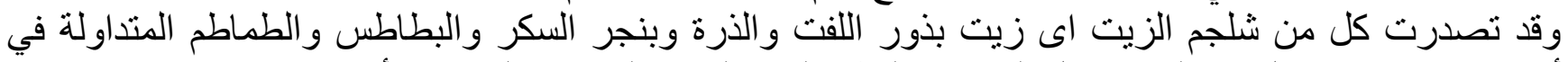

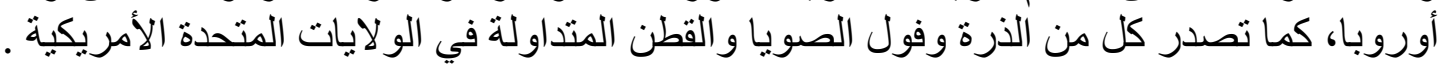

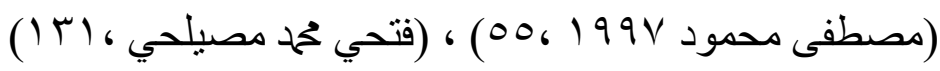

\section{حماية الغذاء من التثوث}

يِعتبر الغذاء وسيلة سهلة لنقل الميكروبات الممرضة، لذلك يجب منع تلوث الطعام و الماء بالميكروبات للمحافظة

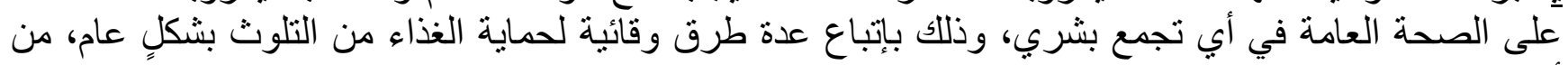
أهمها:

إجراعات للحد من التثوث الغذائى غسل الأيدي واجب قبل تناول الطعام لمنع انتقال الملوثات إليه.

هنالك إجر اءات و عو امل مساعدة للحد من التلوث الغذائي يجب على الأطفال إتباعها : (من البرنامج المقترح). • اختيار الأطعمة والمشروبات الطازجة والابتعاد عن الأغذية المحفوظة بقدر الإمكان.

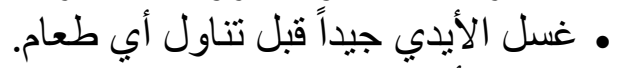

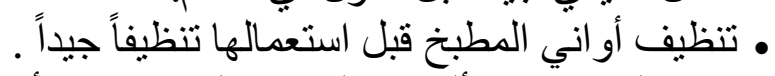

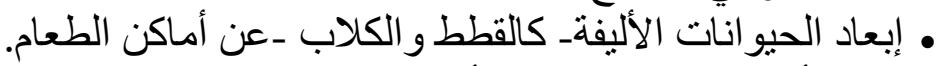

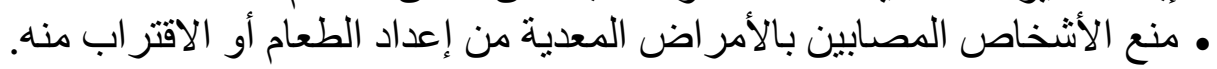

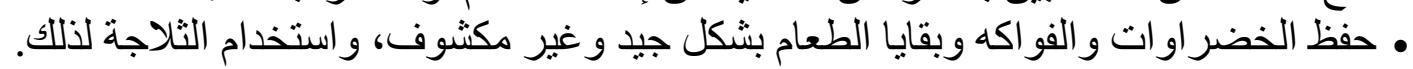

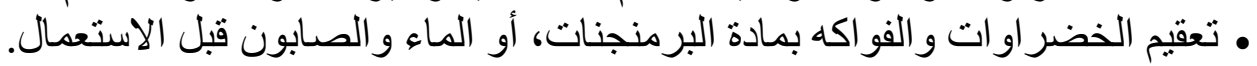

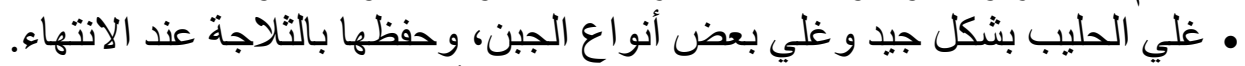

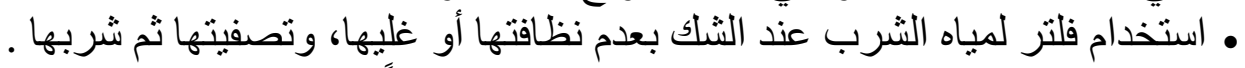

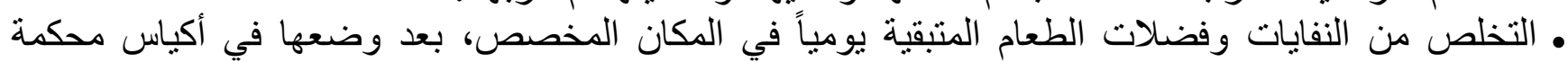
الإ غلاق. 


\section{ما هو السرطان؟ - ان}

تتكون أعضاء و أنسجة أجسامنا من لبنات صغيرة تسمى الخلايا .السرطان هو مرض يصيب هذه

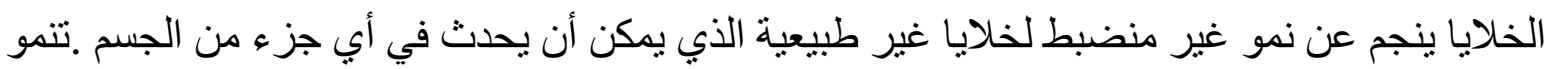

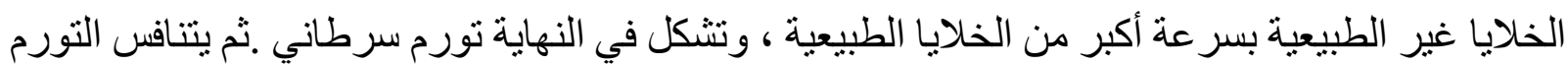

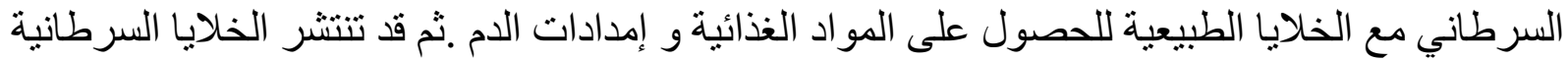

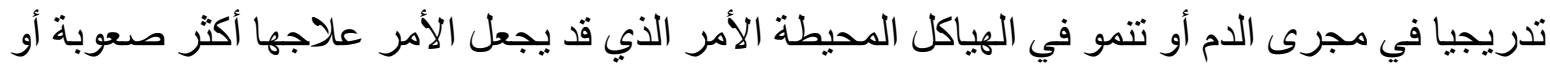

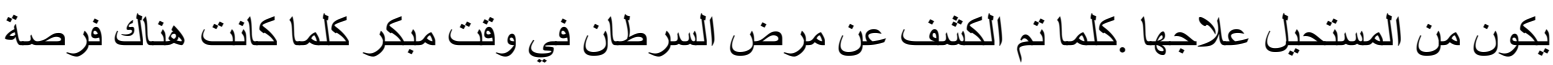
أفضل لعلاجه و العيش لفترة أطول.

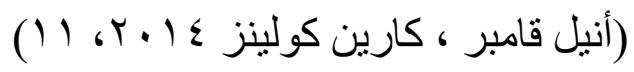

الأنواع المختلفة من مرض السرطان؟

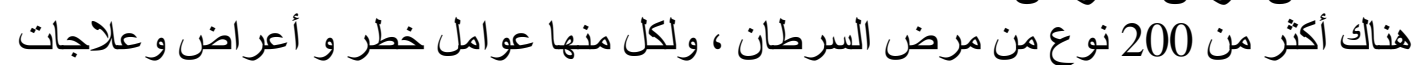

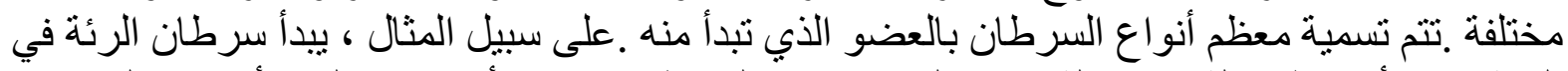

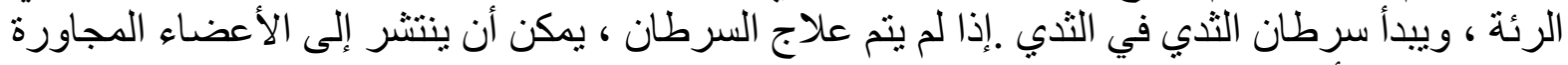

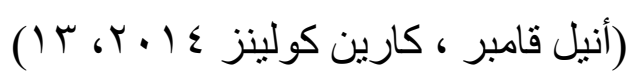

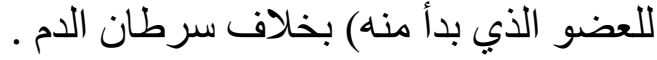

ما هي عوامل الخطر لمرض السرطان؟

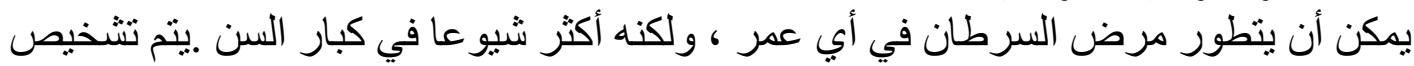

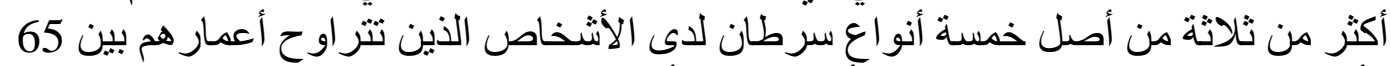

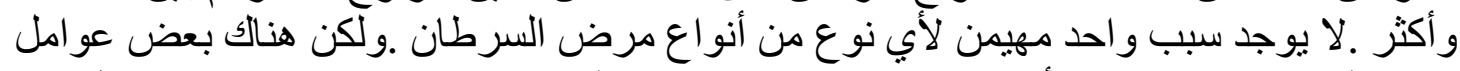

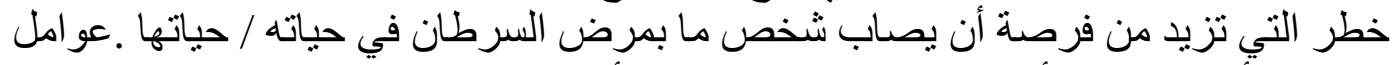

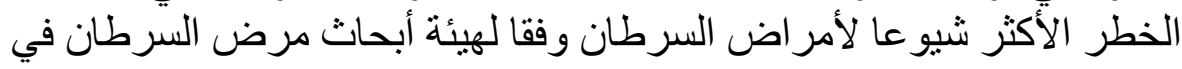

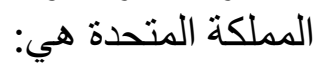

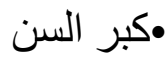

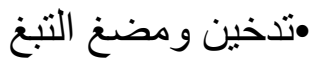

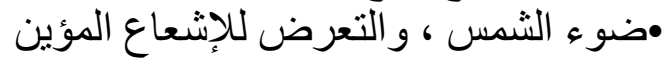

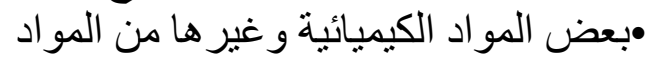

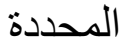

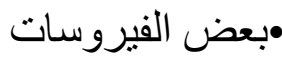

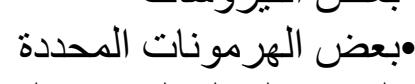
• (التاريخ العائلي لمرض التران السرطان • الكحول

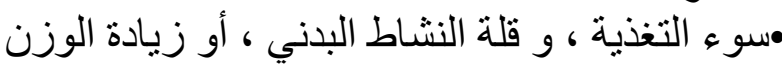

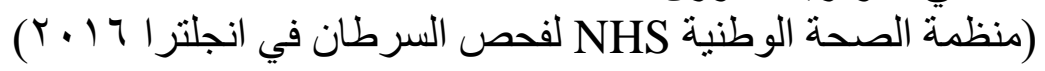

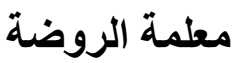

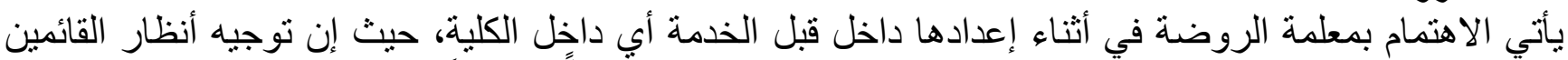

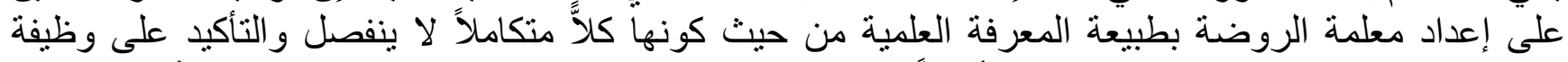

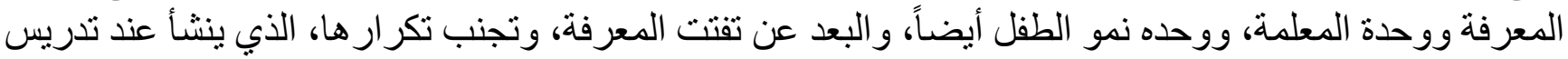

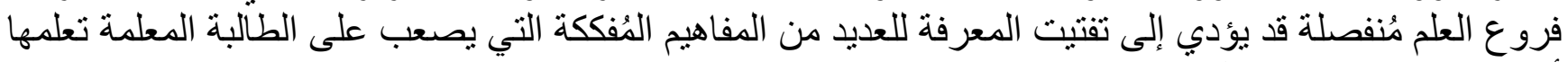
أو تعزف عن در استها قبل ألخدمة. 
وقد تكون معلمة أكثر عُرضه للنسيان لا تستخدم شيئًاً مما تعلمته داخل الكلية في أثثاء إعدادها فيكون دور ها مُهمش، ويظهر

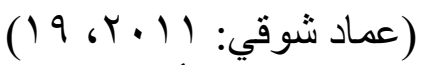

على أطفالها في تكوينهم الفكري و المعلومي.

ومعلمة الروضة هي أحد عناصر مقويات العملية التعليمة تحتاج لتطوير في إعدادها وتطوير دائم في أثناء خدمتها

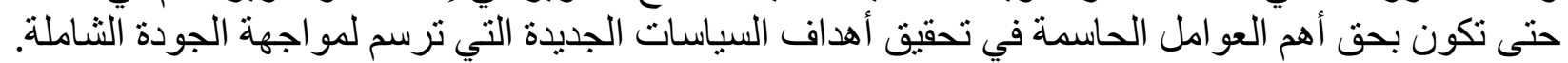

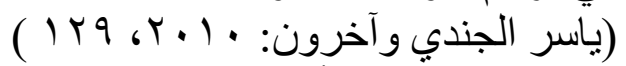

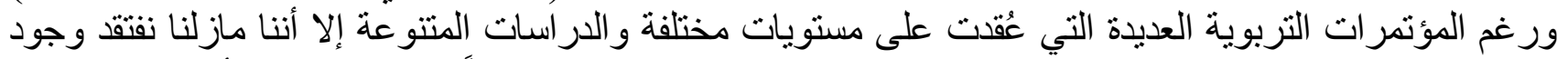

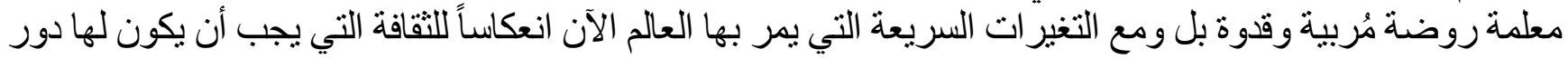

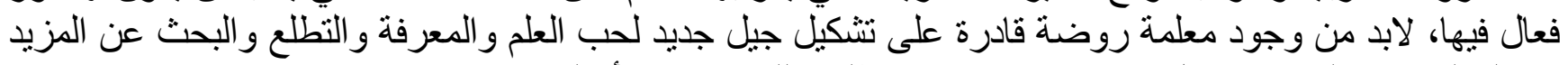

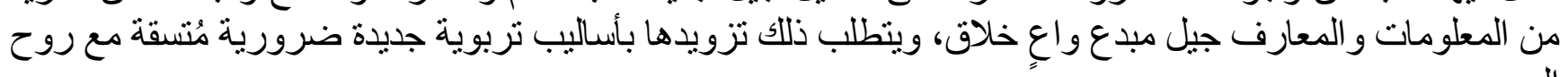

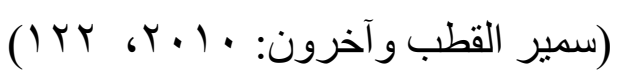

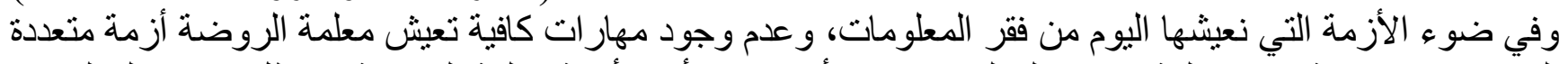

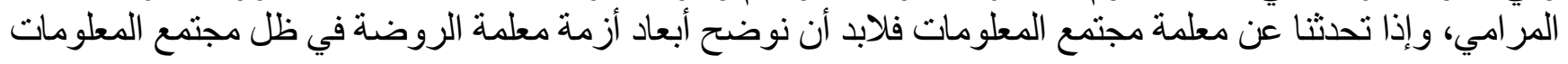

عدم وجود فلسفة و اضحة لإعداد معلمة الروضة وتدريبها ور عايتها. وهي:

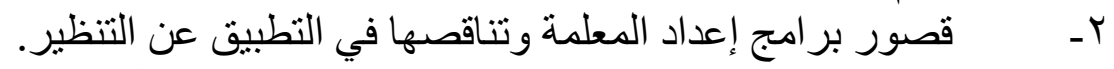

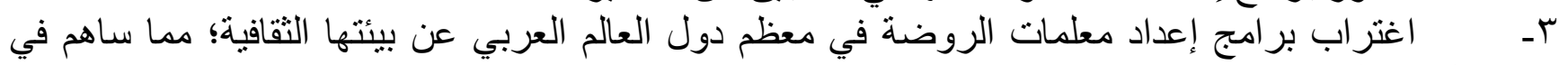
ترسخ التبعية التربوية.

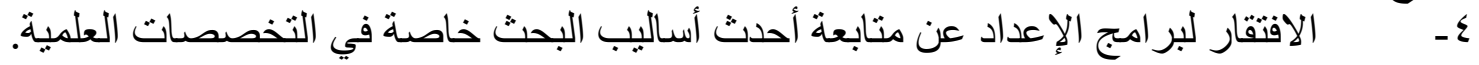

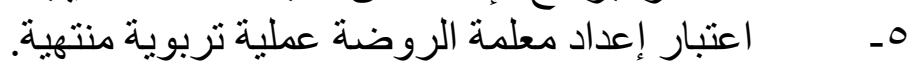

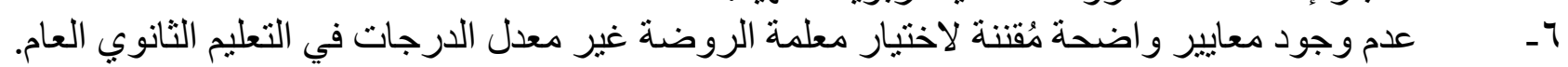

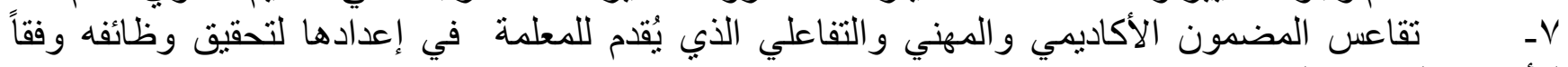
للأهداف التربوية المر غوبة.

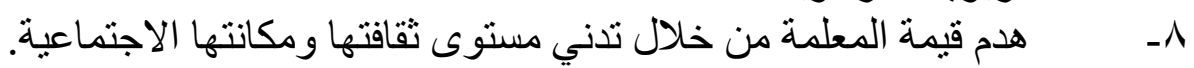

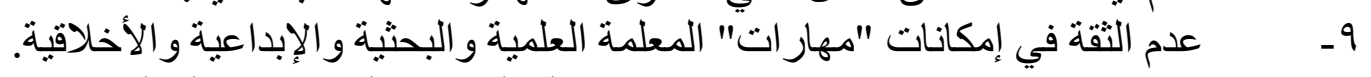

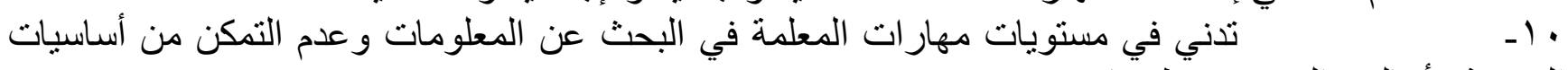

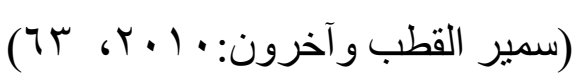
المعرفة وأساليب البحث وتوظيفها. و إن تحقيق البناء المتكامل لشخصية الطفل في هذا العصر تشمل بنيتها على معارف ومهار ات واتجاهات يكفل

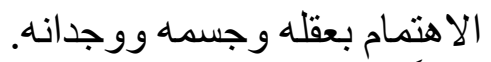
عقلاً: يبحث بعثل عن المعرفة من مصادرها ها المتعددة فيكتسبها ويوظفها توظيفاً إجرائياً يساعده على تسخير تلك

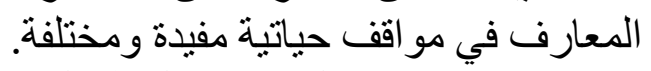
مهارة: يكتسبها الطفل من خلال العهل العل وفة والتطبيق والتجريب، وتصبح ممارسة المهارة و التدرب عليها في الصغر

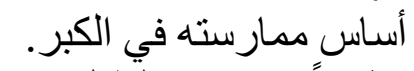

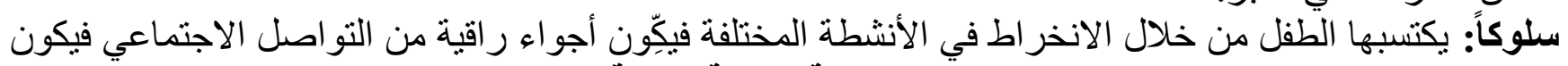

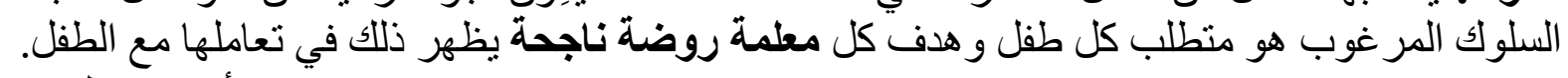

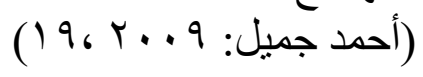

مفهوم الوعي الوقائي: وتعرفه نادية محمود بأنه "نشاط شعوري يصوية يصدر عن الفرد نتيجة رد فعل ما وغالباً ما يكون هذا النشاط الوجداني

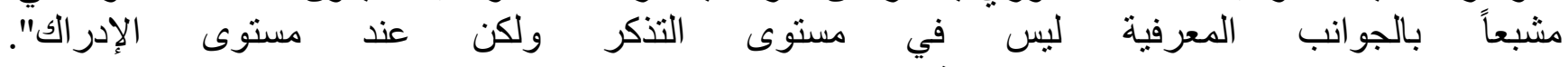

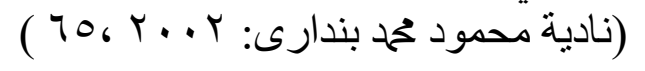




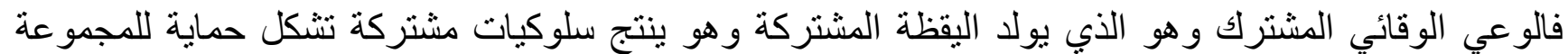

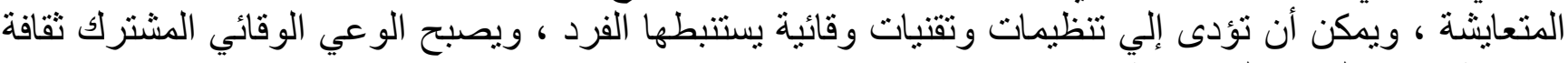

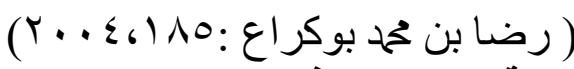
مشتركة تحمى الفرد و المجمو عة الئة وفي حدود علم الباحثة هناك عدد من الاراسات التي عنيت في تتمية التثقيف الغذائي

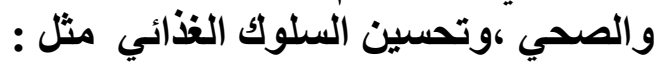

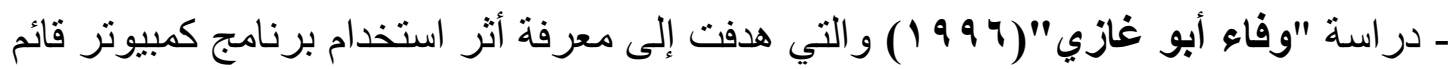

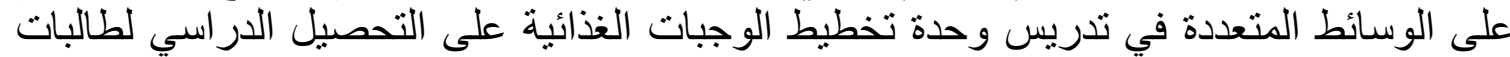

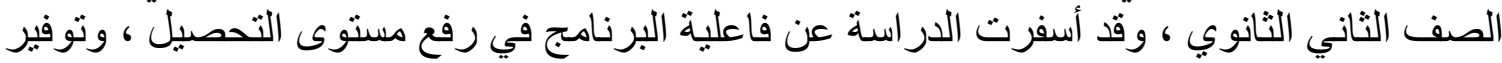

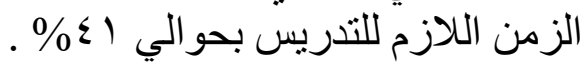

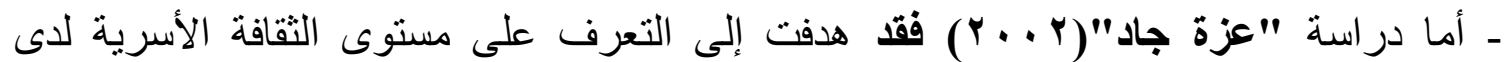

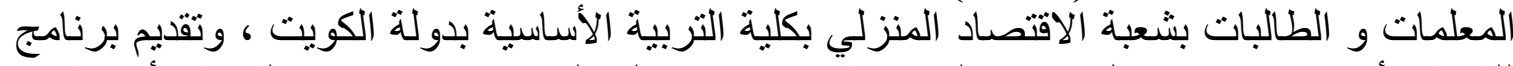

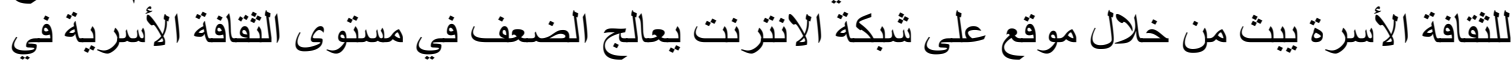

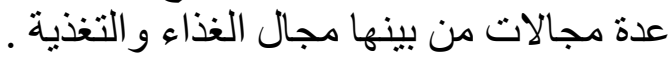

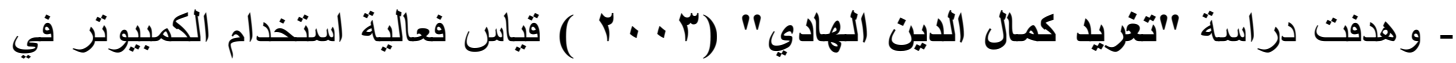

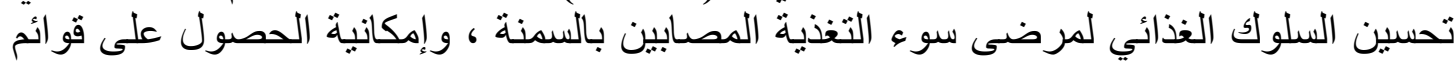

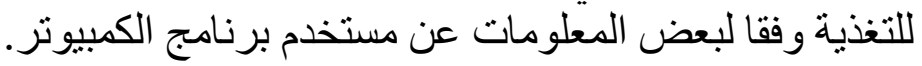

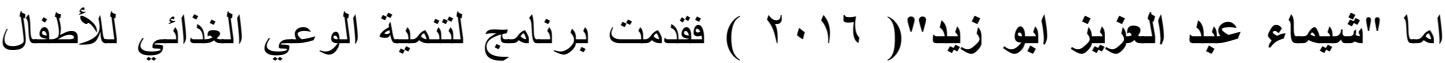

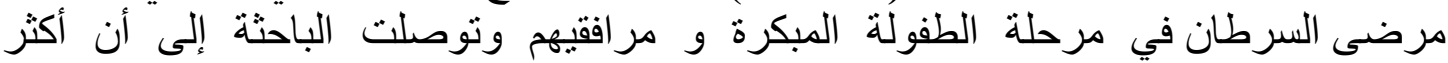

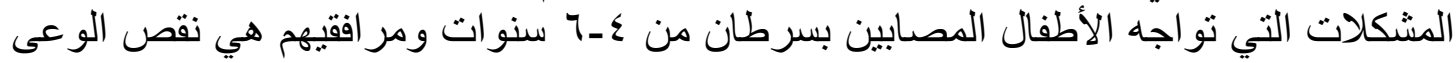

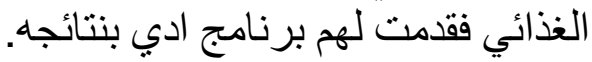

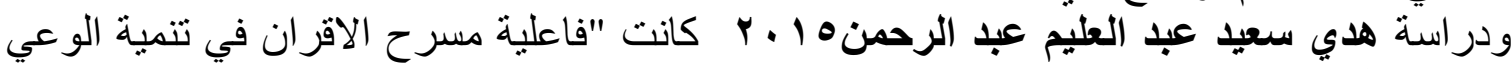
الصحي الوقائي لتلاميذ المرحلة الابتدائية "

ويتضح من عرض الدراسات السابقة أهمية تنمية الثقافة الغذائية والوعي الغذائي من خلال البرامج

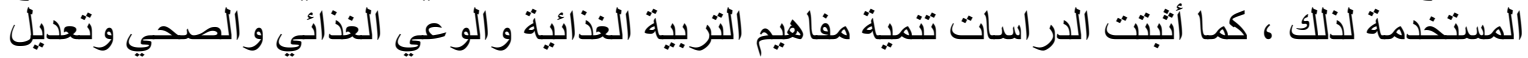
العادات الغذائية الخاطئة ، وتحسين الممارسات الغذائية اليومية واستخدام الوسائط المتعددة للطفل

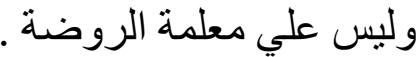

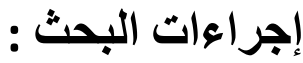

$$
\text { - مامت الباحثة باستخدام الأدوات التالية: }
$$

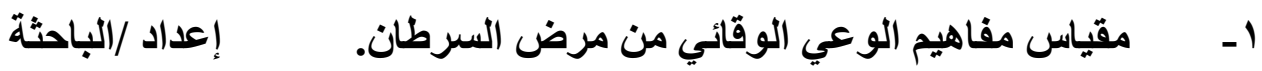

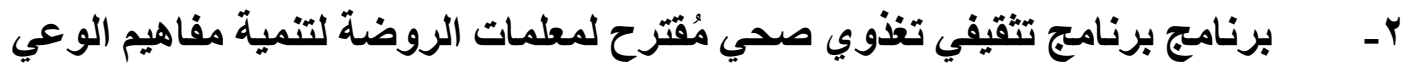

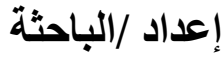

$$
\text { الوقائي من مرض السرطان. }
$$$$
\text { وفيما يلي وصف تفصيلي لهذه الأدوات: }
$$ 


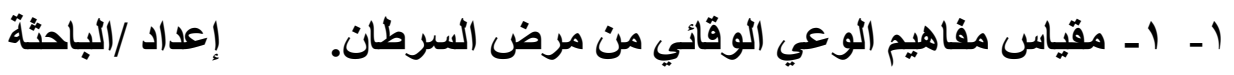 الهذف من المقياس: - الت يهذف هذا المقياس إلى قياس مفاهيم الوعي الوقائي من مرض السرطان

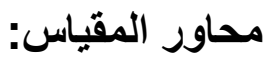
حُددت محاور هذا الدقياس فى ضوء الإطـار النظرى والدراسـات السـابقة التى إهتمت بتحليل مفاهيم الوعي الوقائي ، وطرق تنميتها وقياسها وقد حُددت مفاهيم الوعي الوقائي كما يقيسهـا الدقياس فى في

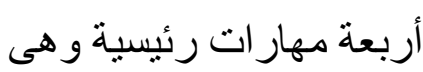

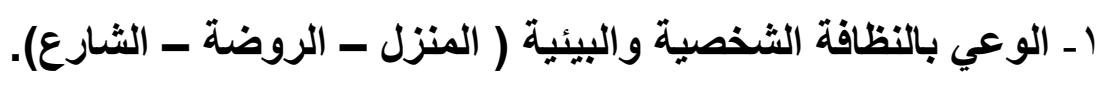

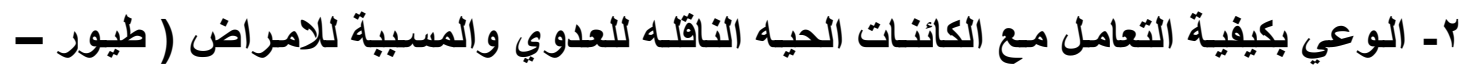

$$
\text { حيوانات - حشرات). }
$$

r- الوعي بالغذاء الصحي للحد من السرطان.

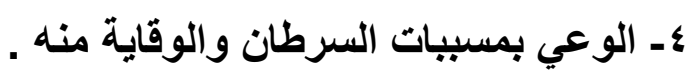

إعداد الصورة الأولية للمقياس:

صيغت مفر ادات المهار ات الرئيسية للمقياس فى صورته الأولية كالاتى- سؤال مفتوح ، (أسئلة

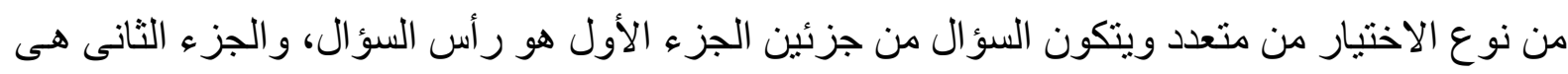

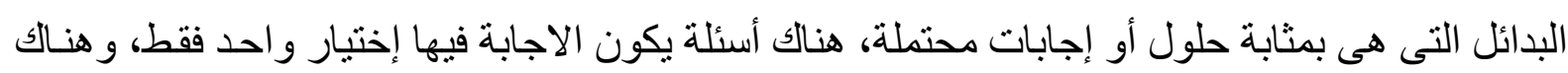
أسئلة يكون الإختيار أكثر من إختيار واحد وعدد البدائل للسؤال الواحد أربعة بدائل، و عدد الأسئلة للكقياس كاملا (Y ( ) سؤ ال، بالإضافة إلى التعليمات العامة وقد راعت الباحثة عند صياغة تلك التعليمات أن تكون و اضحة ومباشرة، بحيث تفهمها كل معلمـة وتسـاعدها على فهم طريقة الإجابـة على الأسئلة،

وتضمن التعليمات الهرف من الإختبار، عدد الأسئلة ونو عهاهو كيفية الإجابة عنها وتمثلت في الأتى :

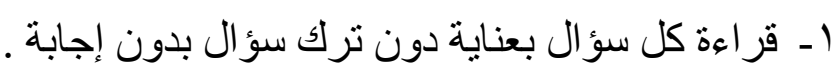

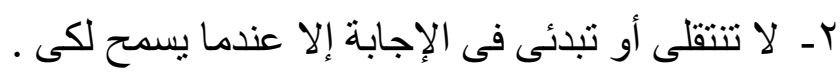

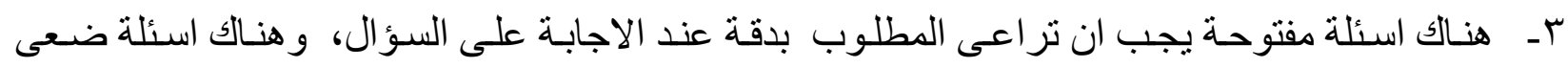
علامة صح داخل المربع المقابل للعبارة الدالة على الإجابة الصحيحة و الذى يتم إختيار ها.

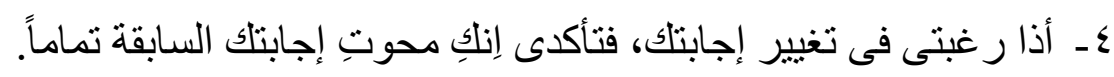
0ـ تصحيح المقياس :

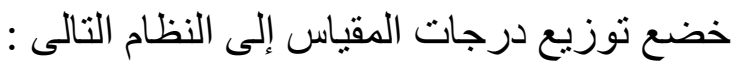


المفهوم الاول (الوعي بالنظافة الثخصية والبيئية ( المنزل ـ الروضة ــ الثارع): خصص الثص لها (r ا ) درجة وز عت على سؤ الين . الاوعي

المفهوم الثـاني (الـوعي بكيفيـة التعامـل مـع الكائنـات الحيـه الناقـــه للعدوي والمسبية للامراض ( طيور - حيو انات - حشرات): خصص لها (Y I ) درجة وز عت علي سؤ الين.

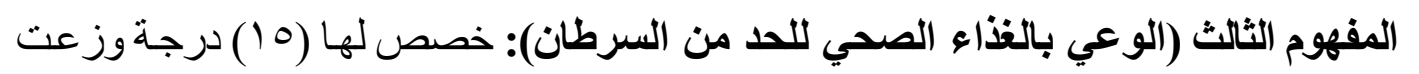
على 0 أسئلة. المفهوم الرابع (الوعي بمسببات السرطان والوقاية منه): خصص لها (7) درجات وزعت على ب أسئلة. الخصائص السيكومترية لمقياس مفاهيم الوعي الوقائي من مرض السرطان:

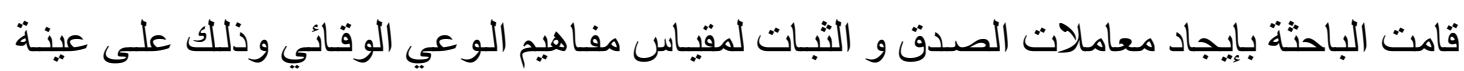
قو امها ·r معلمة.

أولاً معاملات الصدق اعتمدت الباحثة على إيجاد معـاملات الصدق لأبعاد المقياس على صدق المحكين، و الصدق العاملى .

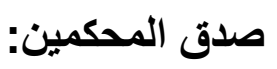
قامت الباحثة بعرض المقياس فى صورته الأولية على عدد من الخبر اء المتخصصين فى مجال المناهج وطرق التدريس مصحوبا بمقدمة تضمنت توضيح مجال البحث، الهدف من المقياس، التعريف الإجر ائى للتعلم الذاتى وذللك بهدف التأكد من: 1 - تمثيل محاور الاختبار ومفرداته لمفاهيم الوعي الوقائي كما حددها التعريف الإجرائى.

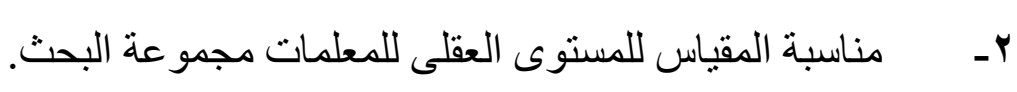

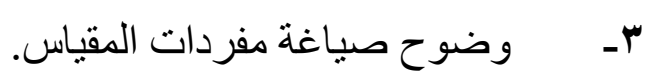
ع- ـ الصحة العلمية لمفردات المقياس. وبعد تلقى الإجابات من المحكمين قامت الباحثة بحساب نسبة الاتفاق بين المحكين حول الملاحظات

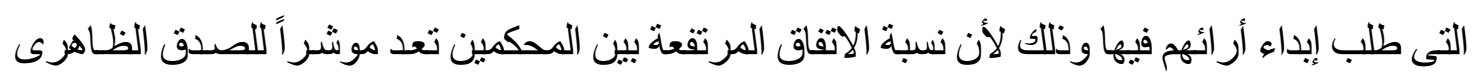
للمقياس، وتحسب نسبة الاتفاق بالمعادلة التالية: 


$$
\text { عدد مرات الاتفاق }
$$

$$
1 \cdot x
$$$$
\text { العدد الكلي(عدد مرات الاتفاق + عدد مرات }
$$

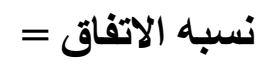

(الاختلاف)

و الجدول التالى يبين نسب الاتفاق بين المحكمين على تللك الملاحظات

$$
\text { جدول (1) }
$$

\begin{tabular}{|c|c|c|}
\hline نسبة الإتفاق & الملاحظـــة & $\hat{r}$ \\
\hline$\% 94$ & كما حدثيل محاور التعريف المقياس ومفرداته لمهار ات البحث عن المعلومات & 1 \\
\hline$\% 90$ & مناسبة المقياس للمستوى العقلى المعلمات مجموعة البحث. & r \\
\hline$\% 9 \leq$ & وضوح صياغة مفردات المقياس. & $r$ \\
\hline$\% 9$. & الصحة العلمية لمفردات المقياس. & $\varepsilon$ \\
\hline
\end{tabular}

نسب الاتفاق بين المحكمين فيما يتعلق بمقياس

$$
\text { مفاهيم الوعي الوقائي لمعلمة الروضة }
$$

\section{التجربة الإستطلاعية للمقياس :}

بعد التحقق من صدق المحكمين أجرت الباحثة تجربة إستطلاعية للمقياس على (• (ب) معلمة من معلمات الروضة في روضة الليسيه فرانسيه بشبرا وراعت الباحثة أن تكون العينة غير عينة البحث الأصلية. وقد هدفت الباحثة من إجرائها للتجربة الاستطلاعية مايلى: ا - - حساب مدى صدق وثبات المقياس. rـ تحديد الزمن الذى تستغرقه اجابة المقياس عند تطبيقه على عينة البحث.

ثم قامت الباحثة بايجـاد معـاملات الصـدق للمقياس وذلك على عينـة من المعلمـات عددها (· ب) معلمة وذللك على النحو التالى:

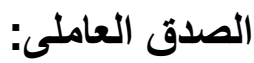

قامت الباحثة بإجر اء التحليل العاملي على عينة مؤلفة من( •ب) معلمة، بتحليل المكونات الأساسية لمفاهيم الوعي الوقائي هوتلنج و قد كثفت نتائج التحليل العاملي عن خمسـة عو امل الجذر الكامن لهما أكبر من الواحد الصحيح على محك كايزر،ثم تدوير المحاور بطريقة فاريمكس Varimaxو أسفرت 
نتائج التحليل العاملى بعد التدوير عن التشبعات الخاصـة بكل عامل و التى تكون ذو دلالة إحصـائية اذا

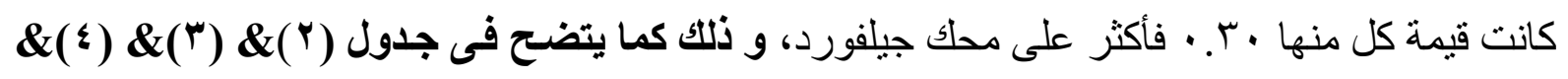

( ( $) \&(\bullet)$

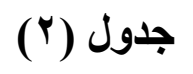

نتائج التحليل العاملي بعد تدوير المحاور للعامل الأول (الوعي بالنظافة الشخصية والبيئية ( المنزل -

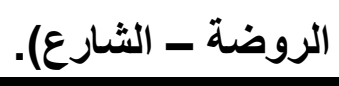

\begin{tabular}{|c|c|c|}
\hline التشبعات & 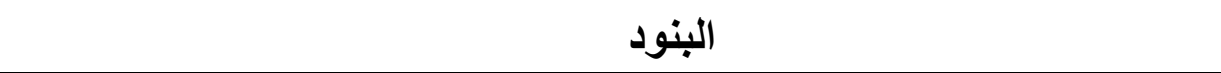 & 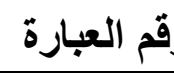 \\
\hline .70 & من خلال معلوماتك قومي ببعض المقترحات لتقومي بها للنظافة الشخصية & 1 \\
\hline .91 & من خلال معلوماتك عليك ان تقترحي ماهي اساليب التعامل مع القمامة & r \\
\hline$r .79$ & الجذر الكامن الجن & \\
\hline
\end{tabular}

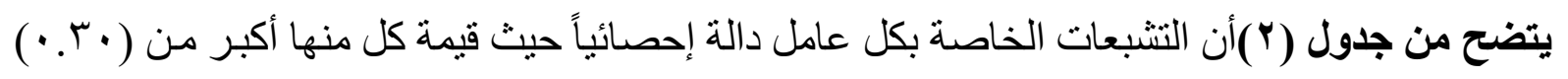
على محك جيلفورد.

\section{جدول (r)}

نتائج التحليل العاملي بعد تدوير المحاور للعامل الثانى (الوعي بكيفية التعامل مع الكائنات

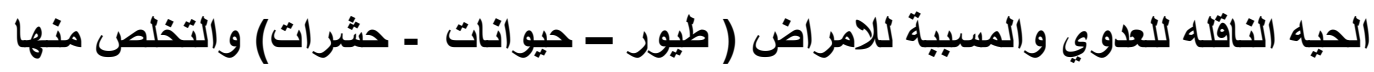

\begin{tabular}{|c|c|c|}
\hline التشبعات & البنود & رقم العبارة \\
\hline$\because .01$ & قترحي بعض الاساليب لتعاملك تعاملك مع الكائنات الحية المختلفة كالاتي & $r$ \\
\hline $.0 \mathrm{r}$ & ماهي طرق التخلص من الحيوانات دون انتقال العدوي من وجهه نظرك & $\varepsilon$ \\
\hline r.vi & الجذر الكامن & \\
\hline
\end{tabular}
بذون نقل العدوي).

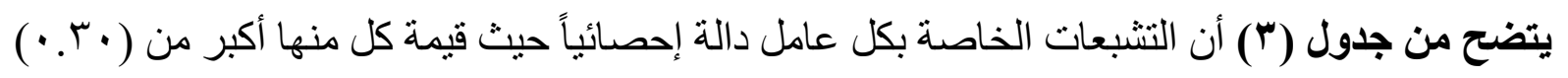
على محك جيلفورد . 


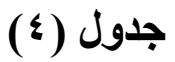

نتائج التحليل العاملي بعد تذوير المحاور للعامل الثالث (الوعي بالغذاء الصحي للدد من السرطان)

\begin{tabular}{|c|c|c|}
\hline 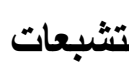 & 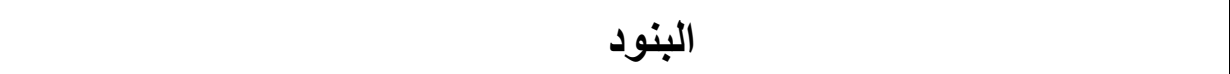 & 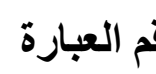 \\
\hline \& & بر أيك ماهو الغذاء الصحي المتكامل للحد من السرطان؟ & 0 \\
\hline. .0 & ظهور الضعف العام والافتقار إلى الشهية والإسهال وسوء الهضم يكون العنصر & 7 \\
\hline צ & ماهي طريقتك البديلة الصحية عن الطهي داخل المنزل؟ & $\mathrm{v}$ \\
\hline$\cdot . \leqslant r$ & ماهي الاطعمة المحفوظة التي بها مكسبات لون وطعم ور ائحة ؟ & $\wedge$ \\
\hline..$\leqslant 1$ & من امثلة التلوث الغذائــــي الإشعاعــــــــ & 9 \\
\hline r.. & الجذر الكامن الجن & \\
\hline
\end{tabular}

يتضح من جدول (؛) أن التشبعات الخاصة بكل عامل دالة إحصائياً حيث قيمة كل منها أكبر من ( ·ـ · ) على محك جيلفورد.

(0) جدول

نتائج التحليل العاملي بعد تدوير المحاور للعامل الخامس(الوعي بمسببات السرطان والوقاية منه)

\begin{tabular}{|c|c|c|}
\hline ل ت لتشبعات & البنود & رقم العبارة \\
\hline .01 & بر أيك ما هي مسببات السرطان ؟ & 1. \\
\hline .0 & من وجهه نظرك ماهي أعر اض مرض السرطان؟ & 11 \\
\hline .00 & كيف تقي نفسك من مرض السرطان؟ & ir \\
\hline $1 . \cdot v$ & الجذر الكامن & \\
\hline
\end{tabular}

يتضح من جدول (•) أن التشبعات الخاصة بكل عامل دالة إحصائياً حيث قيمة كل منها أكبر من ( · . •)

على محك جيلفورد

معاملات الثبات

قامت الباحثة بايجـاد معاملات الثبات لأبعـاد مقياس مهار ات التعلم الذاتى بايجـاد معامل الفـا بطريقة

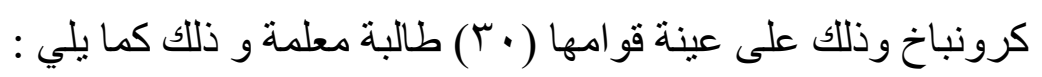
معامل الثبات (الفا) بطريقة كرونباخ عرداخ 
قامت الباحثة بإيجاد معاملات الثبات لأبعاد المقياس كما يتضح فى جدول (†) جدول (7)

معاملات الثبات لأبعاد مفاهيم الوعي الوقائي بطريقة (الفا) كرونباخ

ن.

\begin{tabular}{|c|c|}
\hline معامل الثبات (الفا) & 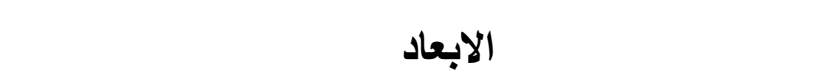 \\
\hline.$\wedge \wedge$ & ا - الوعي بالنظافة الثخصية والبيئية ( المنزل - الثنارع). \\
\hline.$\wedge \varepsilon$ & 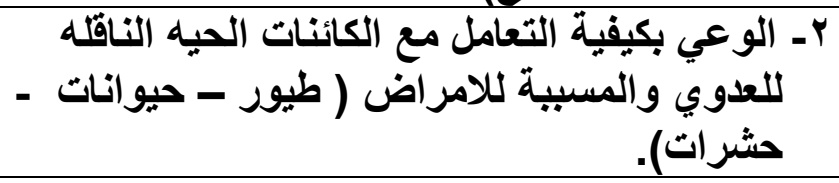 \\
\hline$\cdot . \wedge r$ & rـ الوعي بالغذاء الصحي للحد من السرطان. \\
\hline$\cdot . \wedge \vee$ & ـ- الوعي بمسببات السرطان والوقاية منه . . \\
\hline.$\wedge 4$ & الدرجة الكلية \\
\hline
\end{tabular}

يتضح من جدول (†) إن قيم معاملات الثبات مرتفعة مما يدل على ثبات المقياس ثالثا: زمن المقياس

تم حساب زمن إجابة المعلمات على المقياس عن طريق المتوسط الحسابى لزمن تقديم معلمـات

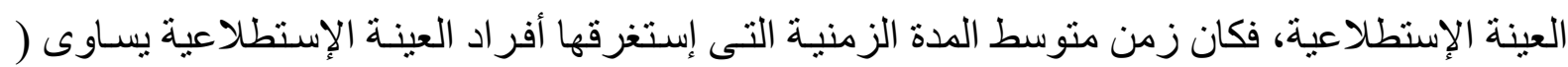
0ـ دقيقة )، وذلك بتطبيق المعادلة التالية: زمن اجابة المقياس =زمن إجابة المعلمة الاولى + زمن إجابة المعلمة الأخبرة $r$

وبما ان زمن إجابة المعلمة الاولى كاتت = · • دقيقة

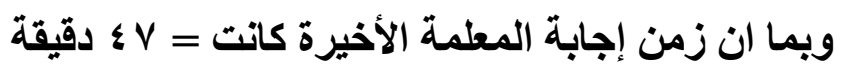
إذا زمن تطبيق المقياس يكون ( 0 ـ دقيقة ) إعداد الصورة النهائية للمقياس : بعد التأكد من صدق وثبات المقياس، أصيح المقياس فى صورته النهائية صالحا للنطبيق، حيث إنتمل على (r ( ) سؤال، وبذلك تكون الدرجة الكلية للمقياس تترواح بين(0 ؛) درجة، و الزمن المتاح للإجابة ( 
r- برنامج تغذوي تثقيفي صحي لمعلمة الروضة لتنمية مفاهيم الوعي الوقائي من مرض السرطان إعداد /الباحثة

البرنامج: مجموعة من الخبرات والأنشطة التي تتضمن المعلومات والمعارف المعارف التغذوية

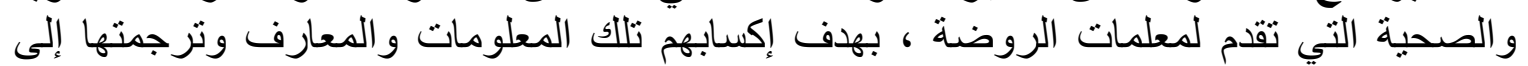
ممارسات يومية صحيحة وتتمية الوعي الوقائي لاطفالهن من مرض التهرئ السرطان.

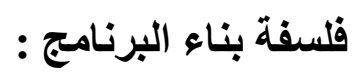

إستمدت فلسفة البرنامج من نظريات النمو المعرفى ونظريات التعلم وفلسفة التربويين السـابقين ويتضح ذلك من خلال النقاط الأتية:

تؤكد النظرية البنائية على أن المعرفة تبنى من قبل المتعلم، وأن المعرفة لايمكن أن تبنى بو اسطة المعلم، وأن المعرفة تفاعل بين الثخص و الثنى (الموضوع)، وإننا نحتاج لبناء الأنشطة التىى تتطلب من المتعلم بناء الأبنية المعرفية من المفاهيم المهمة. يؤكد جون ديوى على إن التعليم الأمثل عنده هو الذي يغرس مهار ات ولا يكدس معلومـات وهذا المبدأ أتبعته الباحثة فى إعداد أنثطة البرنامج حيث يقوم البرنامج على تنمية مفاهيم وترجمتها لمهار ات وليس وليس عرض معلومات

الأسس العامة التي يقوم عليها البرنامج:

ا ـ أن ينمى البرنامج مفاهيم الوعي الوقائي واهم مسببات تلوث الغذاء ومسببات السرطان وفقا لإحتياجـات المعلمة النابعة من احتياجات طفل الروضة. r- أن تحقق محتويات البرنامج الهدف منها. بـ أن ير اعى أنشطة البرنامج الثثلاثة مجالات للأهداف (العقلية المعرفية، النفس حركيـة المهاريـة ،الوجدانيـة

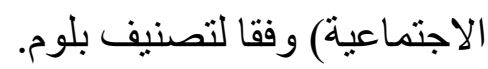
ع- ير اعى عند تصميم البرنـامج نمـاذج من تصميم البر امج التعليميـة مثل نموذج أثنور لتصميم البرامج التعليمية.

0ـ ير اعى البرنامج تنوع الإستر اتيجيات المستخدمة فى تطبيق أنثطة البرنـامج مـا بين إستر اتيجيات التعليم

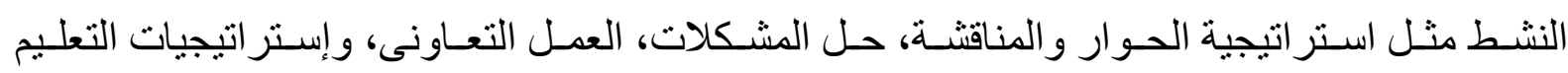

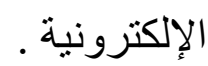

7- أن يكون البرنامج شيق وممتع للمعلمات.

V- - أن ير اعى البرنامج التتوع فى أساليب التقويم من الأسئلة الثفهية، الإختبار ات الورقية الأعمال التعاونية. 
1- أن ير اعى تطبيق البرنامج التقويم المستمر من التقويم القبلى والبعدى و التتبعى للوقوف على مدى فاعلية

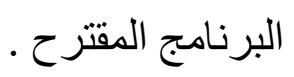
تحديد محتوى البرنامج: يعتبر المحتوى وسيلة تحقيق أهداف البرنامج، ولكى يحققها لابد أن يرتبط بالأهداف ويكون صحيحا وذا

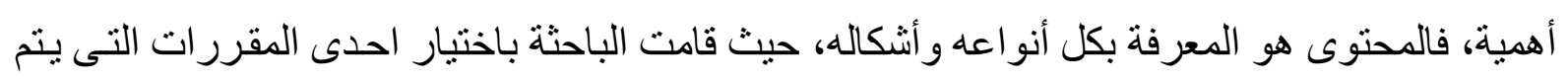

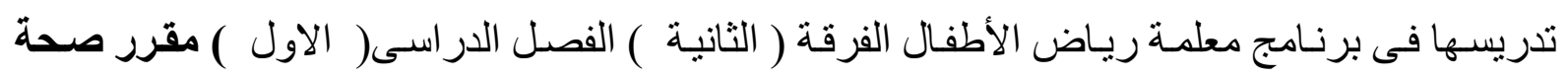

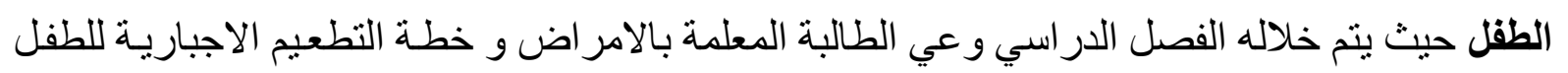
كيفية اسعافات الطفل داخل قاعة النشاط. الأهداف التربوية للبرنامج: يعد التحديد الدقيق للأهداف من أهم خطوات إعداد البرنامج و الهدف عبارة عن صياغة تعبر عما سوف

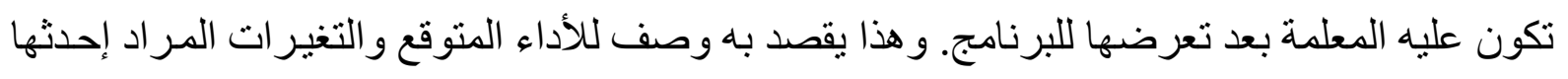
بالمعلمة، و الأهداف بمثابة المعايير التى فى ضوئها يتم تحديد محتوى البرنامج و إختيار التقنيات التربوية (الوسائل و الأدوات التعليمية) و أيضا تحديد الأساليب و إستر اتيجيات التعليم المناسبة، و أيضا تحديد أساليب التقويم المناسبة.

ويمكن تقسيم أهداف البرنامج الى قسمين هما: الأهداف العامة: يهدف البرنامج الى: تئم

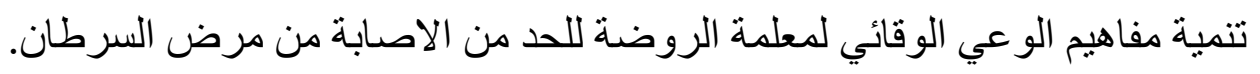

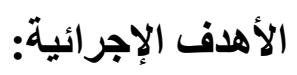
تم تقسيم الأهداف الإجر ائية وفقا لتصنيف بلوم (الأهداف المعرفية ـ الأهداف النفس حركية مهارية )الأهداف الوجدانية) تحديد أنشطة البرنامج :

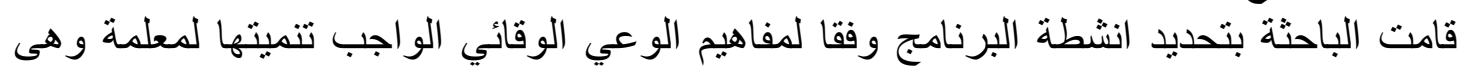

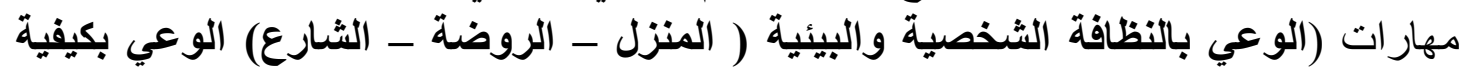

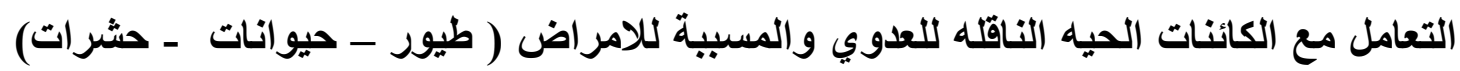

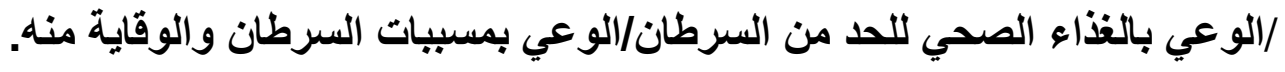

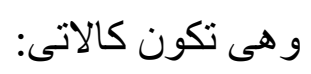

اللقاء الاول: نشاط تعارف بين الباحثة و المجموعة التجريبية (· ب معلمة)، نشـاط تعريفي للباحثة عينة البحث عن مفاهيم الوعي الوقائي لفهم الوقاية من مسببات مرض ولنئ السرطان. 
اللقـاء الثانى حتى اللقـاء الخـامس و العثـرون: تدريب المعلمـات على مفـاهيم الوعي الوقائي بصـورة منفصلة بالصور و التوضيحات المعلوماتية ببرنامج الباور بينت وعرضهه علي المعلمات. اللقـاء السـادس و العشـرون حتى اللقـاء الثـامن و الأربعين: تدريب المعلمـات على الـربط بـين المفـاهيم التو عوية الستة وذلك من خلال التوضيحات والبرمجيات التغذوية ومسببات التلوث في الغذاء التي اعدتها الباحثة.

\section{تحديا إستراتيجيات تطبيق البرنامج:}

وقد تم الإعتماد في تطبيق البرنامج على استراتيجية البرمجيات وعرض الباربوينت واستر ايجية العروض ، و ايضا مجمو عة من الإستر اتيجيات التى تتاسب كل من الأهداف و المحتوى منل إستر اتيجيات التعليم النشط مثل إستراتيجية (حل المشكلات، العمل التعاونى، الحوار و المناقثنة، العصف الذهنى). تحديد أساليب تقويم البرنامج: إعتمدت الباحثة فى تقويم فاعلية البرنامج على: التقويم القبلى: حيث قامت الباحثة بتطبيق مقياس مفاهيم الوعي الوقائي على عينـة البحث (المجموعـة الضابطة و المجمو عة التجريبية) التقويم البنـائى: وهنـا الباحثة تقوم بتقويم كل لقاء من لقاءات البرنـامج لمعرفـة مدى تحقق الأهداف، وتحديد نقاط الضعف والقوة عن المعلمات داخل ادائهم البرنامج المقترح . ومن أشكال التقويم التى تم إستخدامها أثناء تطبيق لقاعات البرنامج مايلى:

1 - إستخدام الأسئلة الثفهية. بـ - ب الأعمال التعاونية.

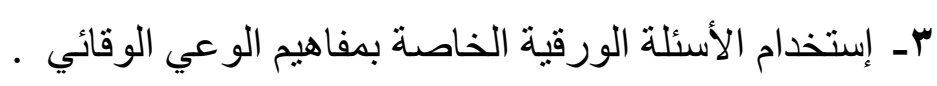
عـ ومن اساليب التقويم التكنولوجيه التى تم إستخدمها موقع التو اصل الاجتمـاعى FaceBook حيث قامت الباحثة بإنشاء صفحة مخصصة للناقش و الحوار حول كل لقاء من لقاءات البرنـامج لتحديد نقاط القوة

$$
\text { هـ ـ بورتفليو خاص بكل معلمة . ـ لقاء من لقاء البرنامج. }
$$

التقويم الختامى: وفى نهاية البرنامج قامت الباحثة بتطبيق مقياس مفاهيم الوعي الوقائي مرة ثانيـة على عينة البحث (المجمو عة الضابطة و المجمو عة التجريبية).

\section{خطوات تنفيذ البرنامج :} لتنفيذ البرنامج قامت الباحثة بالخطو ات التالية: 
1ـ نم أخذ مو افقة إدرة الكلية (كلية التربية للطفولة المبكرة جامعة القاهرة) لإجر اء البحث بإحدى الروضـات بإدارة حلو ان التعليمية بروضة حلو ان التابعة لمدرسة حلو ان الابتدائية المشتركة.

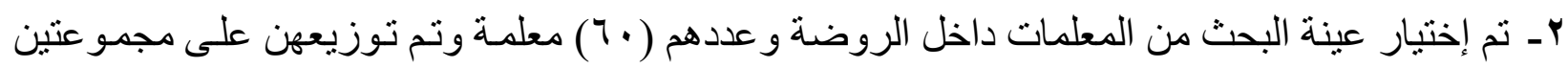

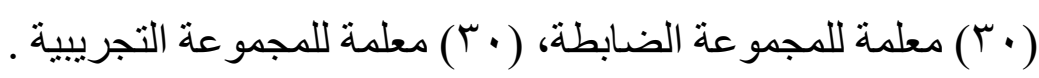

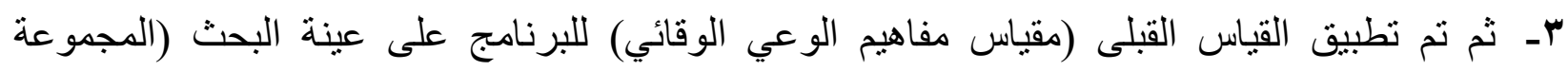

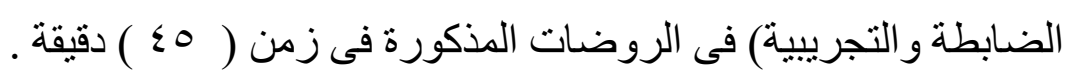
ــ ثم قامت الباحثة بالإتفاق مع المجموعة التجريبية على المو اعيد المحددة (التاريخ، الزمن ، اليوم) لتطبيق البرنامج.

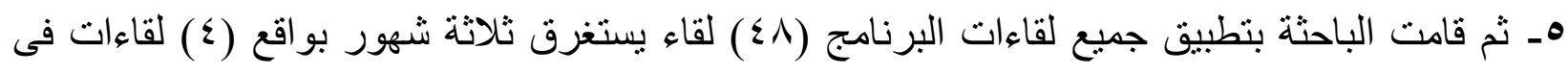
الاسبوع زمن اللقاء الواحد (ساعتين) وكان إجمالى عدد الساعات بالبرنامج (9 (9) ساعة.

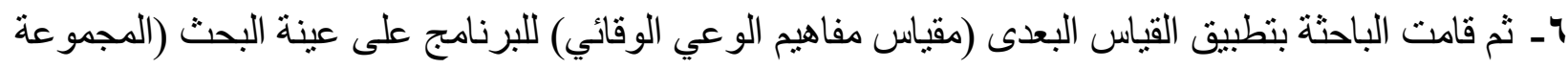

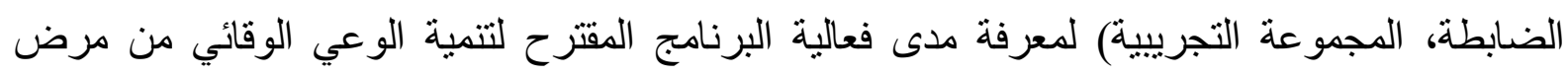
السرطان و الوقاية منه (المجمو عة التجريبية). نتائج الدراسة:

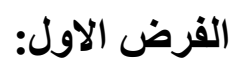

ينص الفرض الاول على انه" توجد فروق ذات دلالة احصائية بين متوسطات درجات معلمات

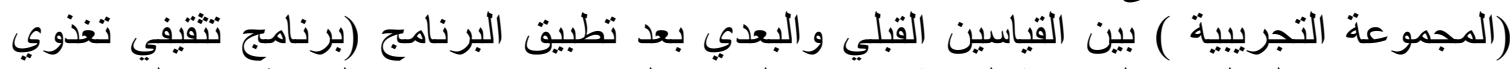

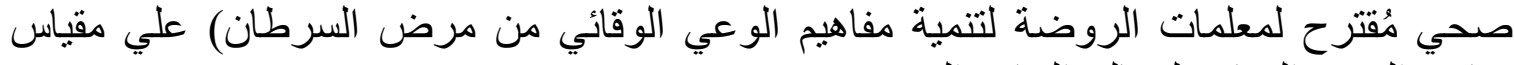
مفاهيم الوعي الوقائي لصالح القياس البعدي".

وللتحقق من صحة الفرض استخدمت الباحثة إختبار " ث" لإيجاد الفروق بين متوسطات درجات الطالبات المعلمـات المجموعـة التجريبية فى القياسين القبلى و البعدى على مقياس الوعي الوقائي كمـا

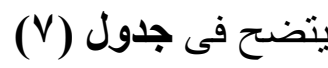




\section{(v) جدول}

الفروق بين متوسطات درجات معلمات المجموعة التجريبية في القياسين القبلي والبعدى على مقياس

\begin{tabular}{|c|c|c|c|c|c|}
\hline \multicolumn{6}{|c|}{ الوعي الوقائي = · ب } \\
\hline \multirow[t]{2}{*}{ إتجاه الدلالة } & \multirow[t]{2}{*}{ الدالة } & \multirow[t]{2}{*}{ 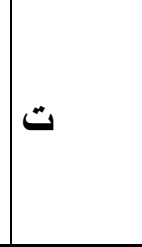 } & \multicolumn{2}{|c|}{ |قياسين القبلى والبعدى بين } & \multirow[t]{2}{*}{ المتغيرات } \\
\hline & & & مج ح ف & م م ف & \\
\hline اتجاه القياس البعدى فى & دالة عند مستوى & $r \leqslant . \leqslant 7$ & $r .19$ & Ir.Ar & (الوعي بالنظافة الثخصية والبيئية \\
\hline اتجاه القياس البعدى & مستوى ا •. & Y7.7ะ & r. $1 \leqslant$ & $1 \cdot . \leqslant \pi$ & 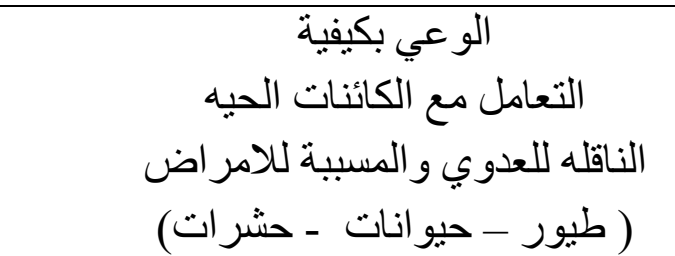 \\
\hline اتجاه القياس البعدى & مستوى ا •.. & 49.9 & r. ro & ir & للحد من السرطان \\
\hline اتجاه القياس البعدى & 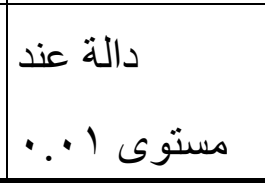 & $r \cdot . r$ & $1 . r 0$ & $0.1 \pi$ & 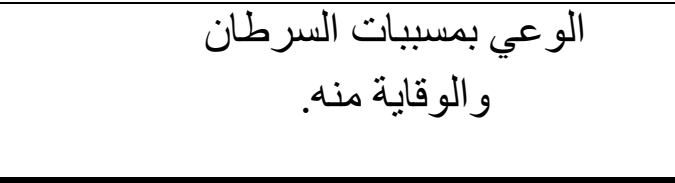 \\
\hline اتجاه القياس البعدى & مستوى 1 •. . & $09.1 \mathrm{~V}$ & $\varepsilon . Y_{T}$ & $\leq 7.0$ & الدرجة الكلية \\
\hline
\end{tabular}

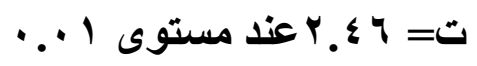

ت =

وتثير نتائج الجدول على ما يلى :

توجد فروق ذات دالة احصـائيا عند مستوى 1 +. •بين منوسطات درجات معلمات المجموعة

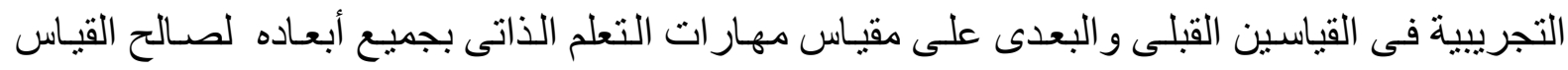

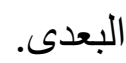

تفسير نتائج الفرض الاول:

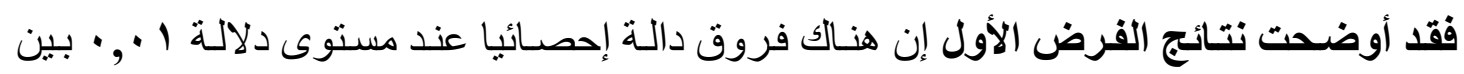

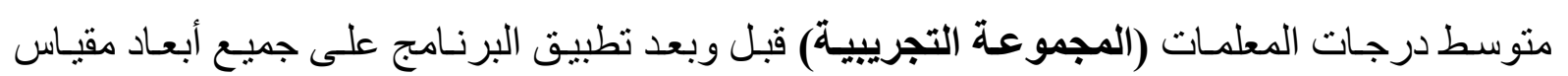


مهار ات الوعي الوقائي من مرض السرطان و الدرجة الكلية للمقياس فى إتجاه القياس البعدى، أى هنـاك فروق ذات دلالة عاليـة بين درجات المعلمات فى كل من التطبيقين، وفى هذا دليل وتاكيد على كفاءة البرنامج وفاعليته وتاثيره الإيجابى الذى أدى إلى تنمية مهار ات الوعي الوقائي من مرض السرطان لدى أفر اد المجموعة التجريبية فى التطبيق البعدى، أى بعد تطبيق البرنـامج (برنـامج تغذوي تثقيفي صحي لتنمية مفاهيم الوعي الوقائي لمعلمـات الروضـة من مرض السرطان ) ويمكن تفسير تفوق المعلمـات (المجموعة التجريبية) فى القياس البعدى على مقياس مفاهيم الوعي الوقائي يرجع ذلك الى: الاعداد الجيد للمادة العلمية التى يحتويها البرنامج حيث تم اعداد المادة العلمية باستخدام استراتيجيات تُحاكي الواقع واستخدامها للانترنت في بحثها عن المعلومات في الثقافة الغذائية في تتمية التحصبل المعرفي لديها ، و الوعي الغذائي و الصحي. فعالية البرنامج المقترح في تحسين نسبة المأخوذ من المخصصات الغذائية اليومية وفقا لـ (RDA ) لدى معلمات عينة البحث ، وتعديل بعض العادات الغذائية غير الصحيحة المنتشرة في البيئة. ثُرجع الباحثة ارتفاع حجم أثر البرنامج سواء في التثقف الغذائي والصحي أو نسبة المأخوذ من المخصصات الغذائية إلى الأثر الفعال لخبرات البرنامج، وذللك يتمثل في الآتي إعطاء المعلمات فكرة عن موضوع البرنامج و أهميته لهم في مرحلة خدمتهم مع الاطفال علي أثنار حماسهم ودافعيتهم للر استه. تشوق المعلمات للاراسة بواسطة الكمبيوتر كأسلوب مغاير للطرق الاخري كعروض الباروبنت و عرض الفيديوهات ودر اسة موضوع هم في أثد الحاجة لمعرفته من العادات الصحية التغذوية التي تؤدي لمرض السرطان التي أذهلت عينة البحث حين شرح الباحثة اثناء البرنامج ان معظمه يقومن بمثل هذه العادات الصحية الخاطئة .

معرفة المعلمة نتائجها أولا بأول ،وتقديم التشجيع والتعزيز المستمر لها عند ايقامها بمعلومة جديدة. تقديم التخذية الر اجعة التي تساعد المعلمة على تصحيح أخطائها وتعديل مسار ها أثناء البرنامج. تتوع أسلوب عرض المعلومات المدعمة بالصوت و الصورة والحركة والألوان . يعمل البرنامج على ربط المعلومات السابقة لدى المعلمات بالمعلومات الجديدة ، وهذا يجعله أكثر تركيز ا وتنظيما للأفكار. مرونة البرنامج في اعطاء المعلمات الحرية في در اسة أي جزء يريدونه أولا، وبالسر عة التي تناسبهن ، وكذلك حريتهن في الاكتفاء بدر اسة جزء معين. 


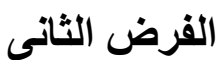

ينص الفرض الثانى على انه" توجد فروق ذات دلالة احصائية بين متوسطات درجات المعلمات

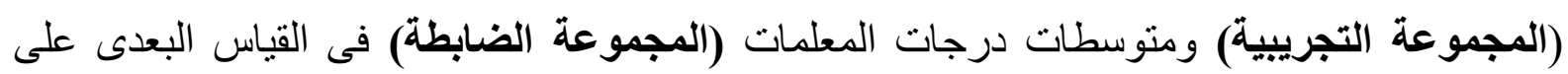
مقياس مهار ات مفاهيم الوعي الوقائي لصالح المجمو عة التجريبية.

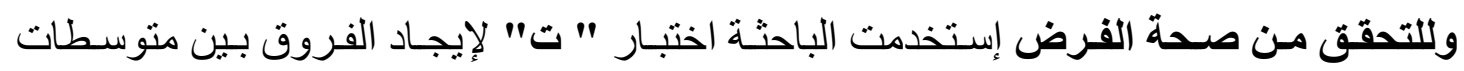
درجات مجمو عتين مستقلنين كما يتضح فى جدول ( 1 ( ) جدول (^)

الفروق بين متوسطات درجات المعلمات للمجموعتين التجريبية والضابطة على مقياس الوعي الوقائي فى القياس البعدى ن =. •

\begin{tabular}{|c|c|c|c|c|c|c|c|}
\hline \multirow[t]{2}{*}{ |تجاه الدلالة } & \multirow[t]{2}{*}{ | مستوى } & \multirow[t]{2}{*}{$ت$} & \multicolumn{2}{|c|}{ نموعة الضابطة } & \multicolumn{2}{|c|}{ ن } & \multirow[t]{2}{*}{ المتغيرات } \\
\hline & & & $r \varepsilon$ & $r_{p}$ & $1 \varepsilon$ & 1 p & \\
\hline لصالح التجريبية & مستوى 1 •. & rA. ro & 1.9 & 10.9 & 1.97 & $r$. & 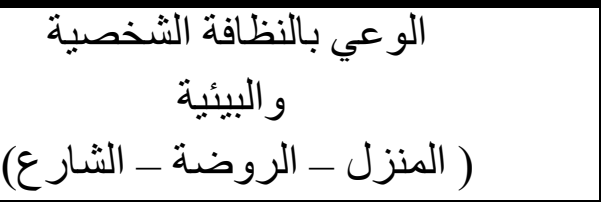 \\
\hline لصالح التجريبية & 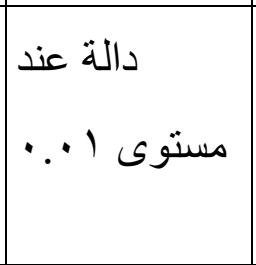 & $r \leq .,$. & $1 . \leq \varepsilon$ & $11 . r$ & 1.Ar & Y). $T$ & 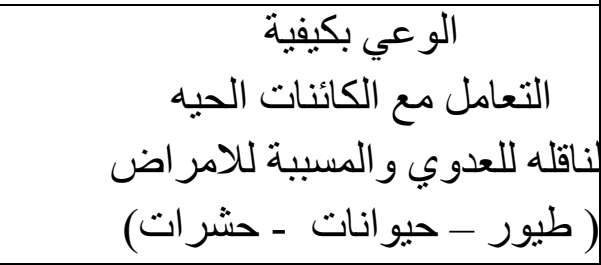 \\
\hline لصالح التجريبية & 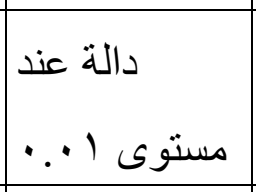 & $r \cdot r v$ & prr & 11.8 & $1 . \wedge V$ & $r \leqslant .1 T$ & 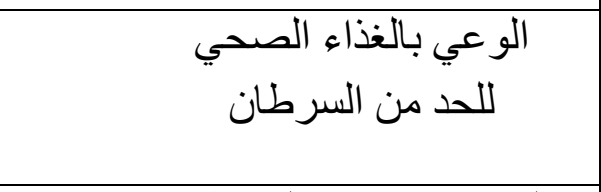 \\
\hline لصالح التجريبية & \begin{tabular}{|l|} 
\\
\\
\end{tabular} & $|A . r|$ & 1.rT & $0 . \wedge r$ & $\cdot 9 r$ & $1 \cdot .97$ & $\begin{array}{c}\text { الوعي بمسببات السرطان } \\
\text { والوقاية منه. }\end{array}$ \\
\hline لصالح التجريبية & 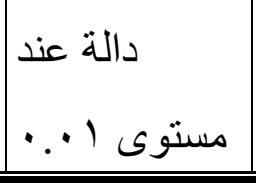 & rv.q. & $\sum . Y_{0}$ & 0.9 & $0 . r$ & $9 \vee . \vee$ & الدرجة الكلية \\
\hline
\end{tabular}

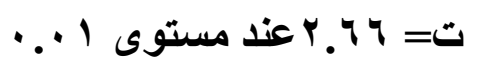

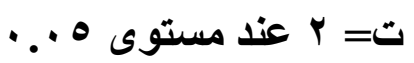
وتثير نتائج الجدول على ما يلى : 
توجد فروق ذات دالة إحصائيا عند مستوى 1 •. • بين متوسطات درجات المعلمات للمجمو عتين التجربيية و الضابطة

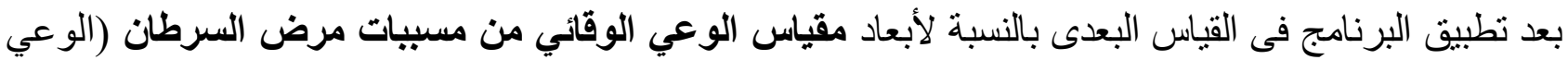

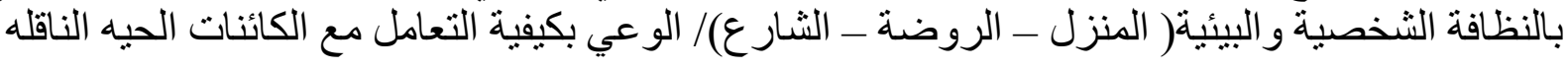
للعدوي و المسببة للامر اض( طيور - حيوانات - حشرات)/ الوعي بالغذاء الصحي للحد من السرطان/ الوعي بمسببات السرطان و الوقاية منه) و الدرجة الكلية لصالح المجمو عة التجريبية.

\section{تفسير نتائج الفرض الثانى:}

فقد أوضحت نتائج الفرض الثانى إن هناك فروق دالة إحصـائيا عند مستوى دلالة ا +, • بين

متوسط درجات المعلمات (المجموعة التجريبية) ومتوسط درجات المعلمات (المجمو عة الضابطة) فى القياس البعدى على مقياس مفاهيم الوعي الوقائي لصالح المجموعة التجريبية وترجع الباحثة هذه الفروق

إن أفر اد المجمو عة الضـابطة لم يتلقو أي خبـرات أو أنـشطة إضـافية تعمل على إستثنارة مفـاهيم الوعي الوقائي لديهن، كما حدث مع أفر اد المجمو عة التجريبية التى تم تطبيق البرنامج عليها وهذا يوضح فاعلية البرنامج فى تنميـة هذه المفـاهيم لدي المعلمة تخصص ريـاض الاطفـال و التي لها الاثر في الوقايـة من مسببات مرض السرطان .

ترجع الفروق لصالح المجموعة التجريبية فى القياس البعدى عن المجموعة الضـابطة وذلك لأن المجموعة

$$
\text { الضابطة لن تتعرض للبرنامج . }
$$

\section{توصيات الاراسة :}

ـ ـ يمكن الاستفادة من البرنامج المقترح في البحث الحالي عن طريق تعميمه في المرحلة الإبتدائية

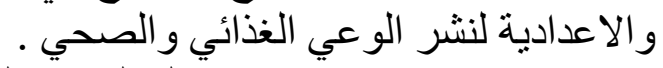

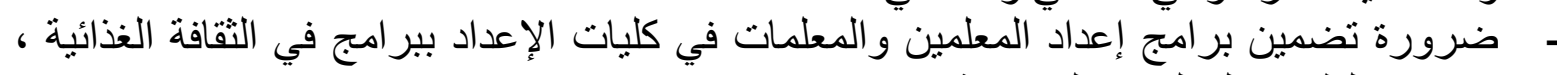

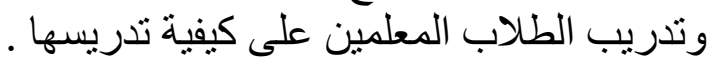
- ضرورة عقد دورات تدريبية للمعلمين و المعلمات في الخدمة وتدريبهم على استخدام التكنولوجيا

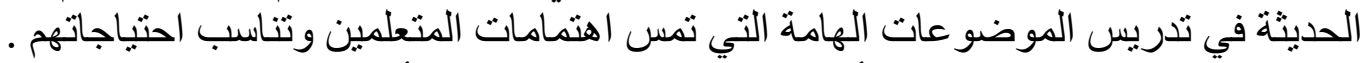

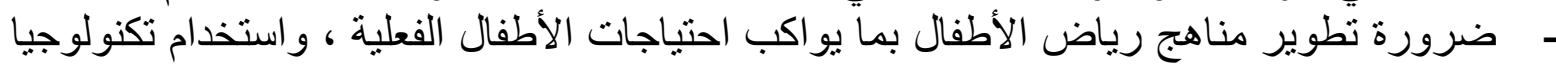
- ضرورة الاهتمام بتنفيذ الأنشطة المختلفة في الروضات لتشجيع الاطفال على الحركة والتفكير

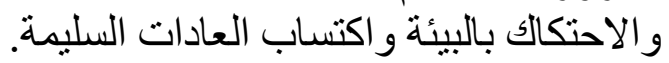

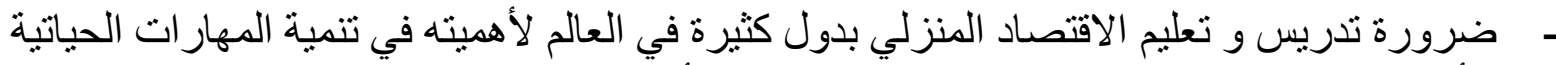

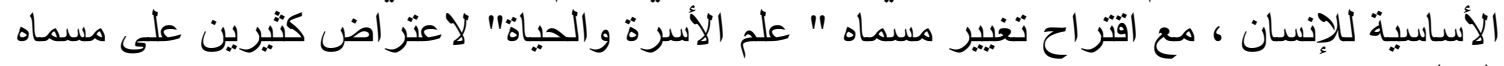
ضرورة التو عية الغذائية بالاهنمام بوجبة الإفطار وإرشاد الأبناء إلى ضرورة تناول طعام الإفطار

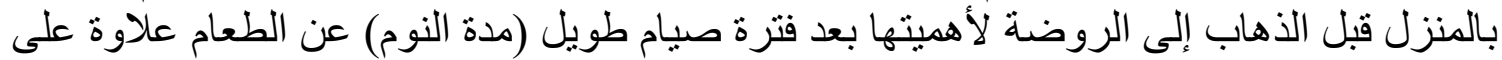

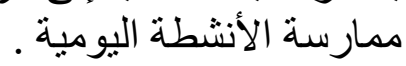
ـ ـ ضرورة التوعية الغذائية بأخطار تناول الأطعمة السربعة والسندونشات الجاهزة خارج المنزل

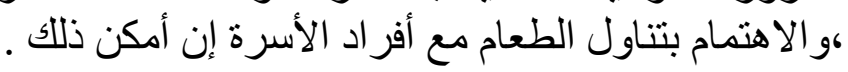


ـ ضرورة التوعية الغذائية بالاهتمام و الحرص على تناول ثنلاث وجبات يوميا وعدم حذف أب وجبة

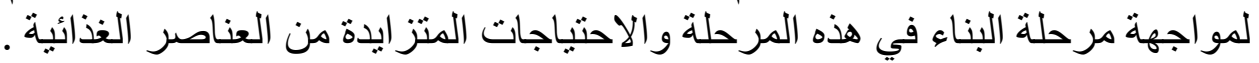

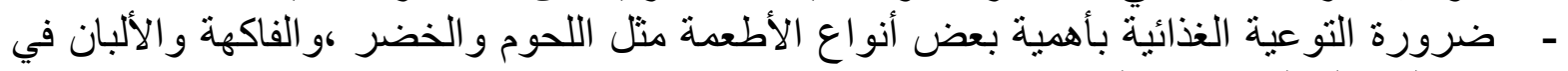

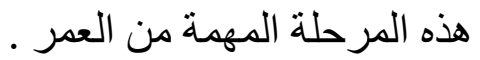

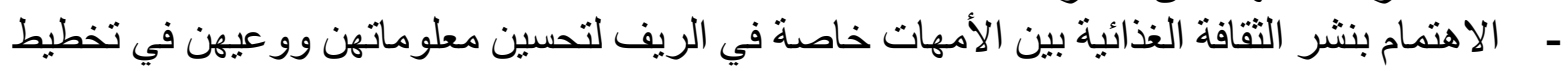

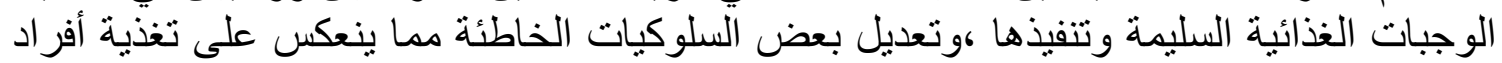
الأسرة جميعا .

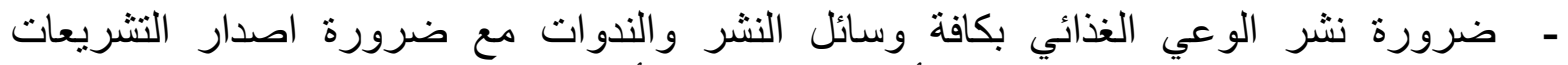

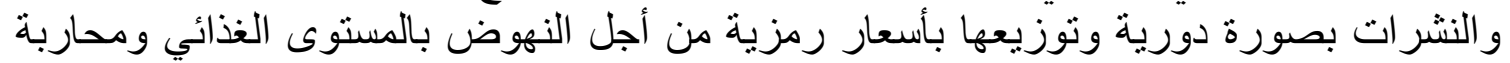

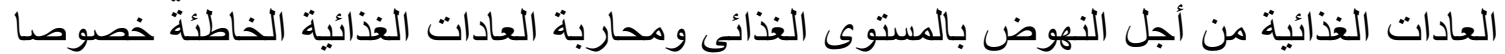
بين الأطفال .

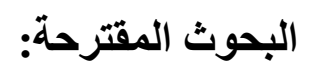

$$
\text { ا ـبرنامج تدريبى لطفل الروضة في الوعي الوقائي من مرض السرطان. }
$$

ץ - برنامج كمبيوتري في التقافة الغذائية على التحصيل المعرفي وتنمبـة الوعي الغذائي و الصحي لاى طفل الروضة. "ـ برنامج كمبيوتري تفاعلي للحد من الامر اض المعدية لأطفال الروضة. 
المراجع:

اولا : المراجع العربية

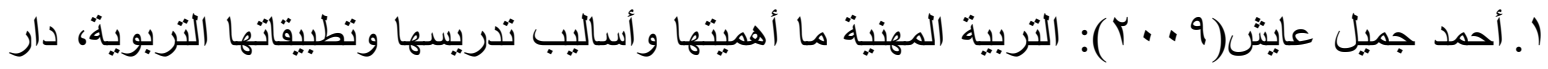
المسيرة للنشر و التوزيع، الطبعة الاولي، عمان - الاردن.

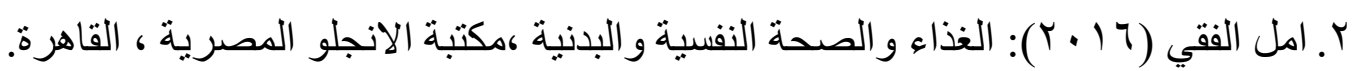

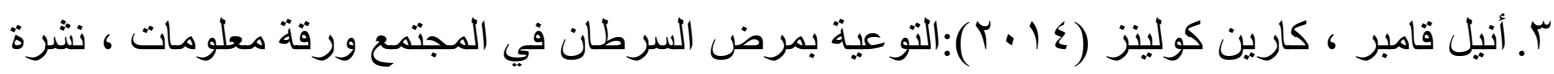

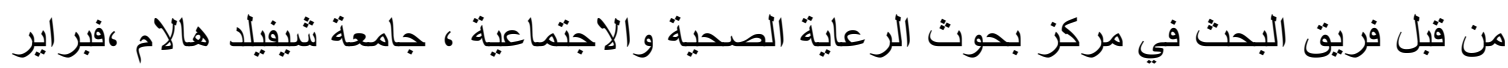

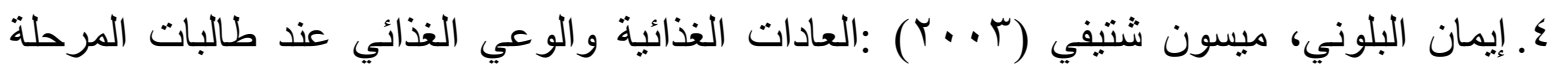

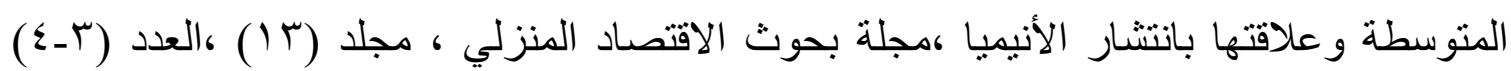
، مامعة المنوفية .

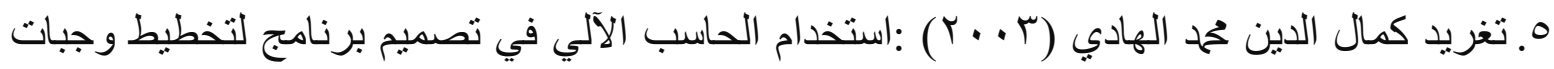

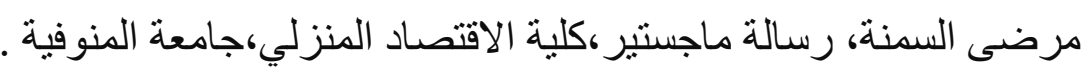

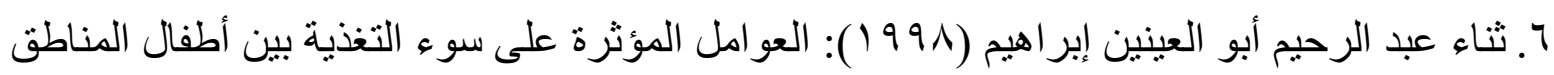

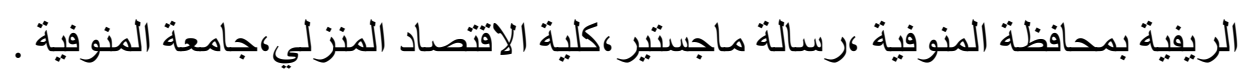

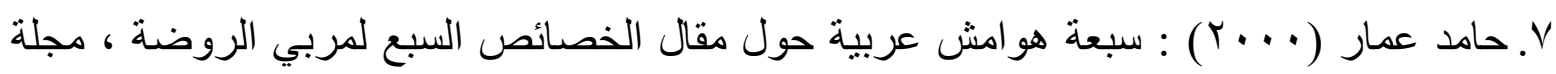

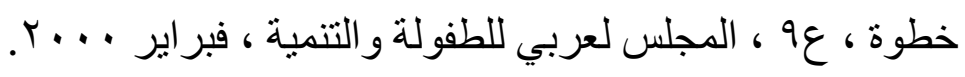

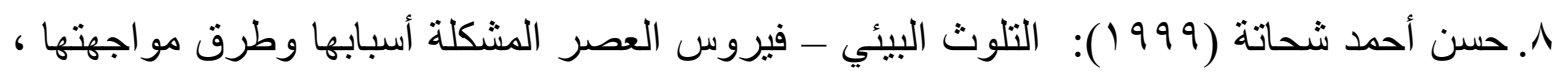
طن ، دار النهضة العربية للطبع و النشر و التوزيع ، القاهرة.

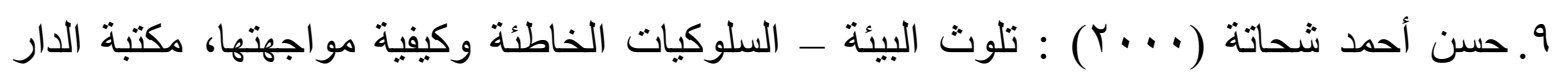
العربية للكتاب ، القاهرة.

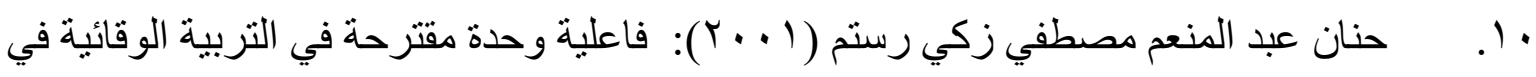

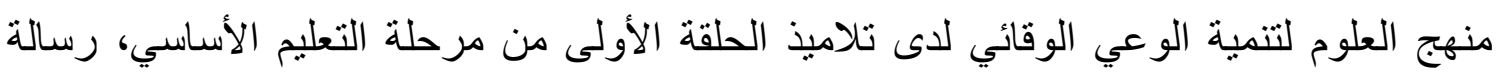

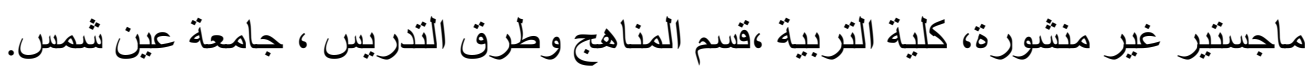

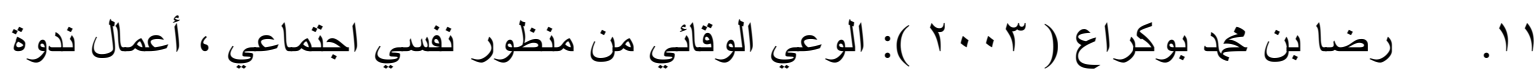

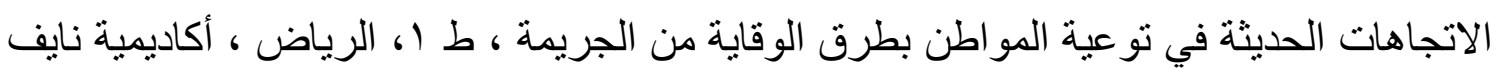

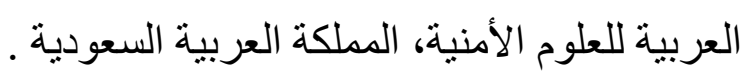

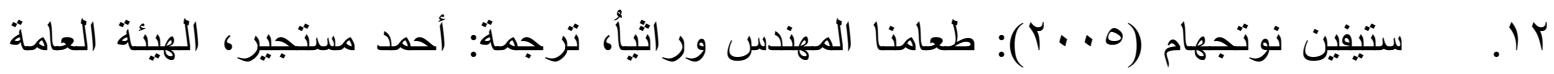
المصرية للكتاب، القاهرة. 


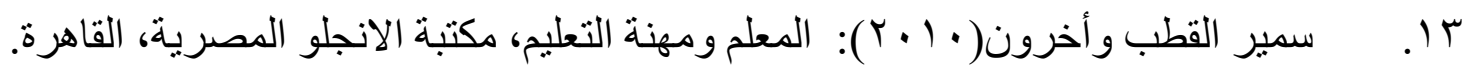
ء ا. سيد سلامة( ( . ب): عرض تجربة المملكة لبرنامج التثقيف الصحي لأمهات الأطفال المعاقين .ورقة قدمت في ندوة التوعية الصحية الأولى "نافذة على التثقيف الصحي"، الرياض ، مستشفى الملك خالد التخصصي للعيون.

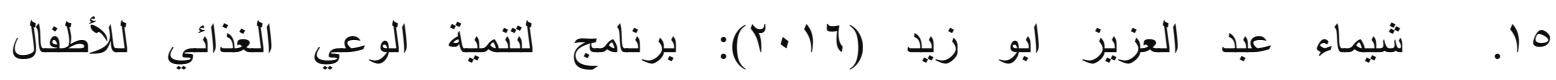
مرضى السرطان في مرحلة الطفولة المبكرة و مرافقهم ، رسالة دكتوراه ، كلية التربية للطفولة

المبكرة، جامعة القاهرة

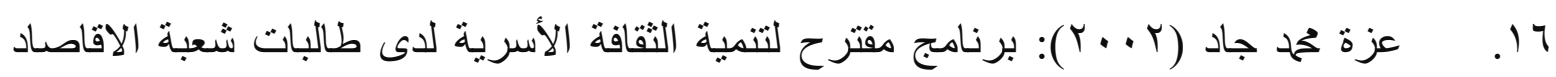
المنزلي يبث من خلال موقع على شبكة الانترنت ،مجلة دراسات في المناهج وطرق التدريس، الجمعية المصرية للمناهج وطرق التدريس بكلية التربية جامعة عين شمس، العدد السابع والسبعون-

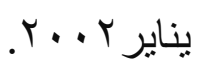

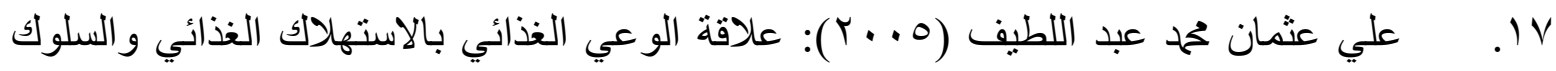
الاقتصادي لدى طلاب جامعة المنوفية ،رسالة ماجستير،كلية الاقتصاد المنزلي،جامعة المنوفية.

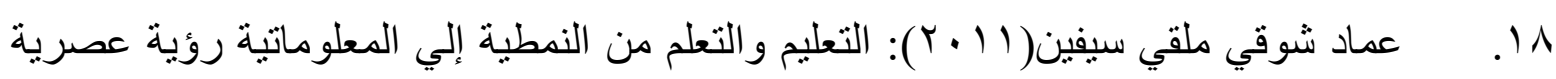
في أساليب التدريس الطبعة الاولي، عالم الكتب، القاهرة. 9 19. فيليب عطية (1999): أمراض الفقر، المشكلات الصحية في العالم الثالث، سلسلة عالم المعرفة (161)، المجلس الوطني للثقافة والفنون والآداب ، مايو ب99 19 ا، الكويت.

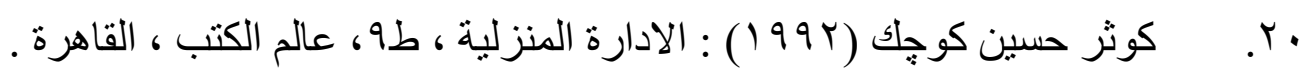

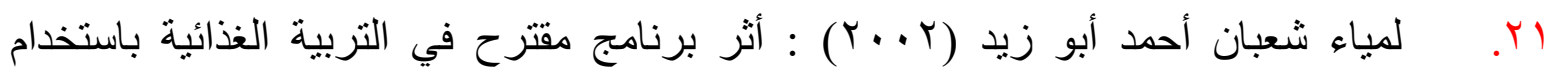
استر اتيجية الثكل (V) على التحصيل المعرفي و المهار ات البدوية ،و الوعي الغذائي لدى معلمات رياض الأطفال قبل الخدمة، بحث منشور في المجلة التربوية، كلية التربية بسوهاج-جامعة جنوب

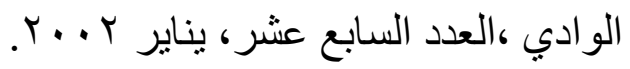

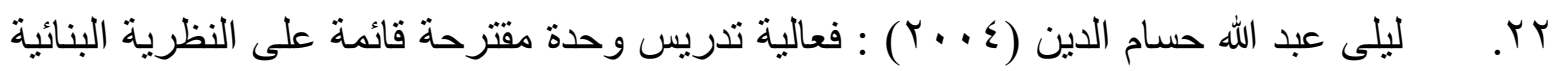
لتنمية وعي طالبات المدارس الثانوية التجارية بالتربية الغذائية، مجلة التربية العلمية،الجمعية المصرية للتربية العلمية بكلية التربية،جامعة عين شمس، المجلد السابع ، سبتمبر ع . . ؟ .

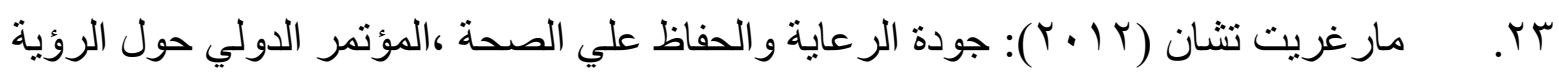

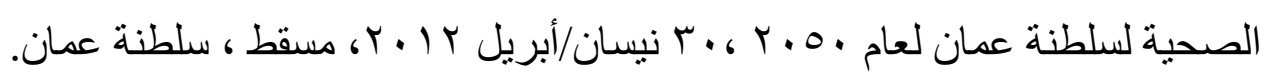

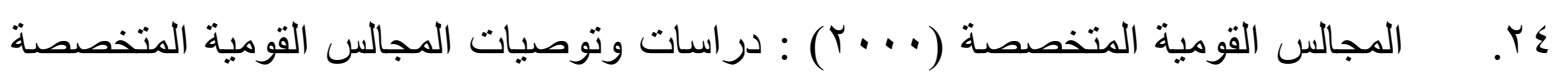
في مجالات العمل الوطني ، رئاسة الجمهورية. 


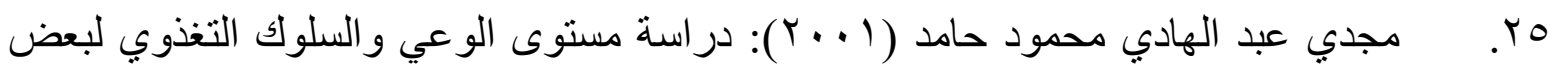
فئات المجتمع المصري ،رسالة ماجستير ،كلية الاقتصاد المنزلي-جامعة المنوفية. جب. . مححد السيد أرناؤوط (1997): التلوث البيئي وأثره على صحة الإنسان، مكتبة الدار العربية للكتاب ، القاهرة.

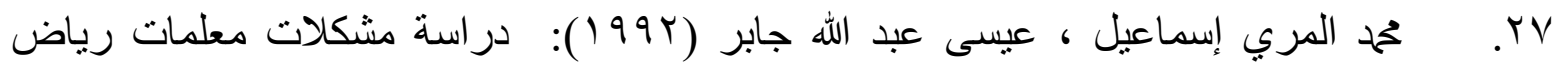
الأطفال بدولة الكويت و علاقتها ببعض المتغيرات ، مجلة كلية التربية ، جا ، ع9 1 ، ، جامعة الز قازيق

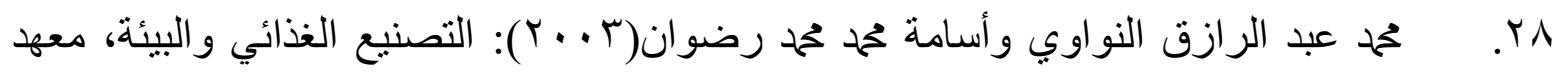
الدر اسات و البحوث البيئية - جامعة عين شمس، القاهرة. 9. . محمد عبد القادر الفقي(999): البيئة - مشاكلها وقضاياها وحمايتها من التلوث، الهيئة المصرية العامة للكتاب، القاهرة.

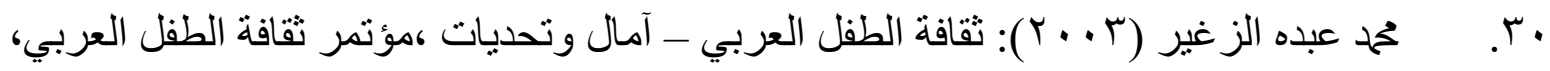
قصر ثقافة الثارقة 7_Vمايو ، الإمار ات العربية المتحدة. اسب. محه نبهان سويلم(1999): التلوث البيئي وسبل مواجهته، الهيئة العامة المصرية للكتاب، القاهرة.

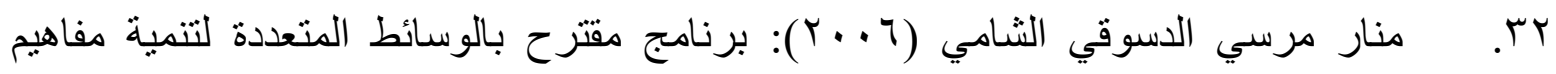
الاقتصاد المنزلي لدى طفل ماقبل المدرسة ،رسالة دكتور اه، كلية الاقتصاد المنزلي ،جامعة المنوفية

سب. منال عبد الرحمن محمود حسنين( 1919 (1) : مدى انتشار سوء التغذية بين الأطفال المصابين بالطفيليات المعوية ،رسالة دكتور ،كلية الاقتصاد المنزلي، جامعة المنوفية

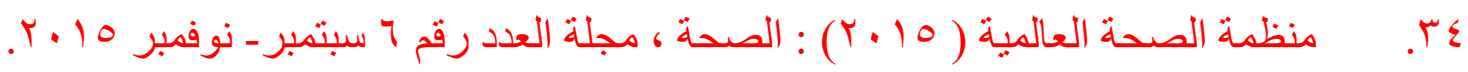

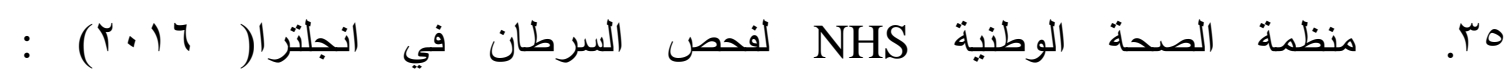
http://www.cancerscreening.nhs.uk جس. مهنا حمح غنايم (·99) (19): من أساليب التربية البيئية في المضمون المدرسي- التربية الغذائية

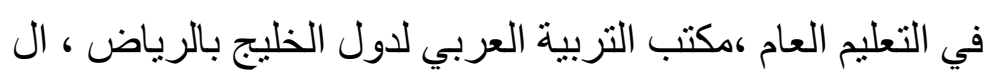

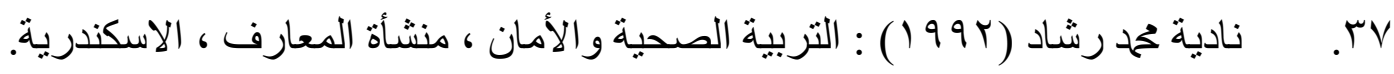

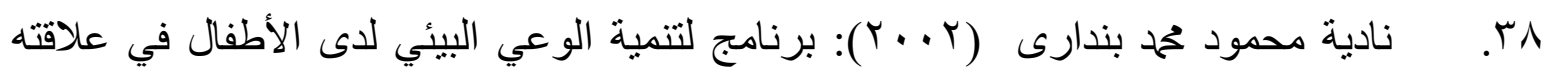
بالتو كيدية ، رسالة دكتور اة ، كلية التربية ، جامعة الزقازيق. 


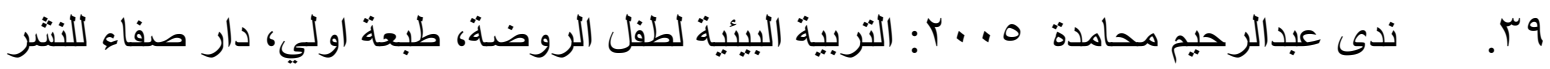

$$
\text { و التوزيع، عمان، الأردن. }
$$

•ع. هدى محمود الناشف (997 (1): رياض الأطفال ، طץ ،دار الفكر العربي ، القاهرة.

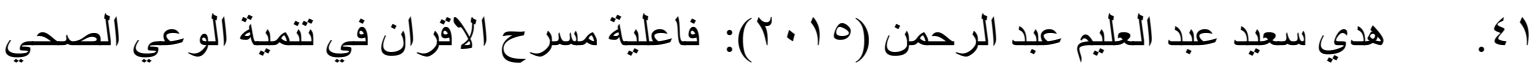

الوقائي لتلاميذ المرحلة الابتدائية ، رسالة دكتور اه غير منشورة، كلية التربية النوعية قسم الاعلام

$$
\text { التربوي، جامعة المنصورة. }
$$

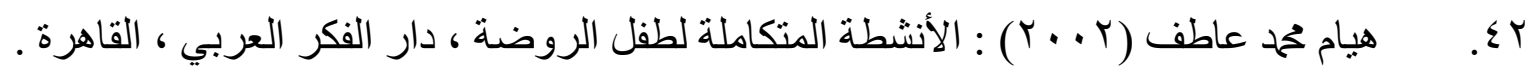

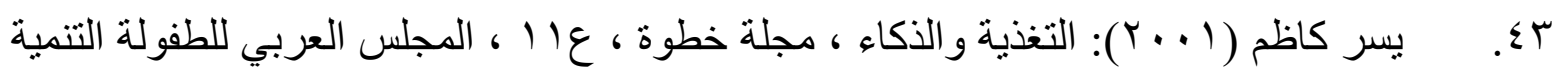

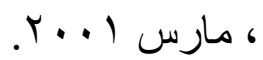

$$
\text { ثانيا : المر اجع الاجنبية }
$$

\section{World Cancer Report 2014}

2. de Martel C, Ferlay J, Franceschi S, et al.: 2012 Global burden of cancers attributable to infections in 2008: a review and synthetic analysis. The Lancet Oncology 2012;13: 607-615.

3. Abed El-Latif, F \& ‘.El-Grwany, H :. (1999): Effects of Air Nollution on Children's Health on : Environmental Management ‘Health and Sustainable Development ‘Alexandria.

4. Chawla, L.: Home for Children in a Changing Society, In E.H . Zube and G.T. Moore (Eds (.Advances in Environment ‘Behavior, and Design vol.3, New York: Plenum.

5. Whalley Margy (2001): Involving Parents in Their Children's Learning ‘ Paul Chapman Publishing Ltd. London.

6. Hosny, G \& ‘.El-Koffa, S. (2002): Patterns Incidence of podiatric Cancer in Alexandria Egypt, From $19 \vee r$ to 2001 ، the Journal of Egyptian Public Health Association ،Vol.Lxxv11, No.5,6,

7. Yerkesr R. \& Haras, K. (1997) : Outdoor Education and Environmental Responsibility, ERIC on Rural Education and Small Schools, Charleston ED No. 414112. 
8. Barfield Lon (2004): Design for Multimedia and the web, London, Pearson Addison Wesley.

9. Yee, C. (2001): the Effects of Computerized Music in Student's Attitude and Achievement of children, UK/ London, University of London, Institute of Education. Ph thesis.

10. Carter, L, Marshall, MD, (1998) toward an educated Health Consumer, Mass Communication and Quality in Medical care.

11. Walter C. Willett and Meir J. Stampfer (2003). "Rebuilding the Food Pyramid" . Scientific American. 288 (1): 64-

71. doi:10.1038/scientificamerican0103-64.PMID 12506426.

12. "Greenpeace Exposes Guangzhou Pesticide Contamination"(2006): ChinaCSR. June 13, 2006.

13. " chemical veggies, Toxic soy sauce, -- food scares hit Vietnam". AFP (Hanoi: Google News). Sep 11, 2007.

14. TribhuMRatta (Nov 05, 2008): "Ban the Colas!". MeriNews. 